SABIRA HAJDAREVIĆ

UDC: $821.14^{\prime} 02-21: 81^{\prime} 373.612 .2$

University of Zadar

shajdarevic@unizd.hr

IVAN BRAICA

neovisni istraživač

braicaivanhr@gmail.com

\title{
SPOMENI PISANJA U GRČKIM TRAGEDIJAMA
}

\begin{abstract}
Sažetak. - Spomeni pisanja u fabulama grčkih tragedija predstavljaju anakronizam; osim Eshilovih Perzijanaca sve se temelje na mitovima mikenskog razdoblja, koje karakterizira gotovo isključivo usmena komunikacija. Ipak, termini kojima se aludira na razne pisane dokumente sporadično se pojavljuju u sačuvanim dramama i fragmentima.

U ovom radu analizirani su termini te vrste u Eshilovim, Sofoklovim i Euripidovim dramama i fragmentima. Naravno, prva referentna točka bili su derivati korijena $\gamma \rho \alpha \varphi-$, a zatim i pojmovi koji uobičajeno označavaju pisane dokumente ili pisma ( $\delta \varepsilon ́ \lambda \tau o \zeta, \pi i v \alpha \xi$ i sl.) i njihov prijenos (derivati od $\dot{\varepsilon} \pi 1 \sigma \tau \varepsilon \lambda \lambda$-). Nakon izdvajanja termina pažljivo je analiziran kontekst stihova u kojima se pojavljuju, a zatim su termini katalogizirani prema približnom značenju (npr. slovo, zapis, slika, pločica, pismo itd.). Zaključno, određena je učestalost pojave svakoga od termina u dramama trojice tragika te je istraženo koriste li autori važnije termine na podudaran način.
\end{abstract}

\section{Uvod}

Iako spomene pisanja pratimo u grčkim književnim djelima još od Ilijade (priča o Belerofontu u VI, 168-170), oni su rijetki prije klasičnog doba, baš kao što je i pisanje dugo bilo neuobičajena aktivnost $\mathrm{u}$ grčkoj svakodnevici jer su i pismenost i materijali za pisanje bili nedostupni širim slojevima društva. Kroz 5. st. pr. n. e. raste postotak pismenih građana, ${ }^{1}$ stoga je logično pretpostaviti da bi i spomeni pisanja mogli biti učestaliji u opusima pisaca tog doba.

Cilj je ovoga rada istražiti kojim terminima trojica tragičara Klasike, tj. Eshil, Sofoklo i Euripid, aludiraju na pisanje. Analizirani termini potječu iz tri kategorije/grupe: metonimijski termini, derivati od $\gamma \rho \alpha \varphi-\mathrm{i}$ derivati od $\dot{\varepsilon} \pi \_\tau \varepsilon \lambda \lambda-{ }^{2} \mathrm{U}$ metonimijske termine pripadaju: $\beta \hat{v} \beta \lambda \mathrm{o} \varsigma$,

\footnotetext{
${ }^{1}$ Hajdarević, 2019: 3.

${ }^{2}$ Prva grupa obuhvaća pisane dokumente nazvane po materijalu/predmetu na kojemu se nalaze (npr. drvena pločica), što je svojevrsna metonimija. Termini druge grupe podrazumijevaju poveznicu s činom pisanja, a termini treće mogu označavati pisma ili njihovo slanje, stoga ih je nužno uključiti u analizu. Ideja za ovakvo grupiranje termina koji će biti pretraživani potječe iz Ceccarelli, 2013: 15. Rad se tematski dijelom naslanja i na Hajdarević, 2019, ali ona u centru pažnje ima pisma (tj. prvenstveno Euripidov opus) i naratološku
} 


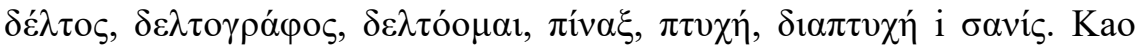

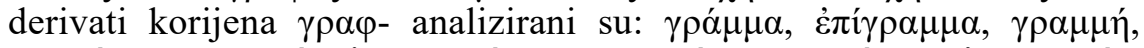

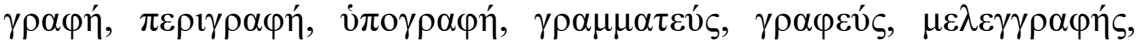

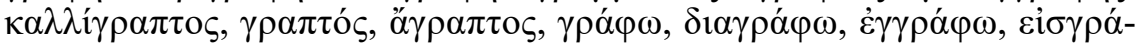

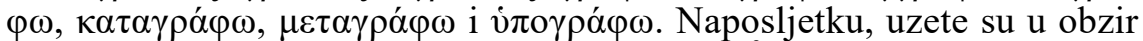
izvedenice od $\dot{\varepsilon} \pi \imath \sigma \tau \varepsilon \lambda \lambda-; \dot{\varepsilon} \pi \imath \tau \dot{\varepsilon} \lambda \lambda \omega$ i $\dot{\varepsilon} \pi \imath \sigma \tau 0 \lambda \dot{\eta}^{3}{ }^{3}$ Opusi autora promatraju se odvojeno; u svakome poglavlju navest će se koji su termini pronađeni, koliko se puta spominju i u kojim dramama, uz detaljnu analizu konteksta u kojima se pojavljuju i definiranje (približnih) značenja koja poprimaju. Konačni rezultati istraživanja bit će na pregledan način prikazani u skupnoj tablici na kraju rada, bit će određena učestalost pojave svakoga od termina u dramama trojice tragičara te provjereno koriste li autori termine na podudaran način ili ne.

\section{Eshil}

Pretraživanjem očuvanih Eshilovih tragedija i fragmenata pronađena su 42 termina koji se mogu odnositi na pisanje. ${ }^{4}$ Čini ih 16 različi-

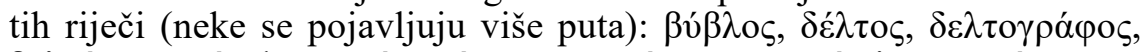

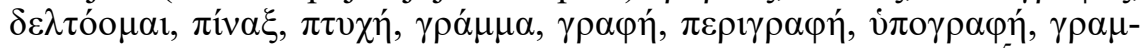

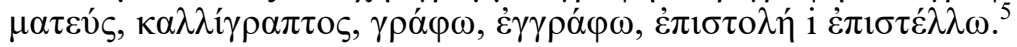

\subsection{Metonimijski termini}

Imenica $\beta v ́ \beta \lambda o \varsigma$ pojavljuje se dvaput (Supp. 761 i 947), ${ }^{6} \delta \varepsilon ́ \lambda \tau o \varsigma$

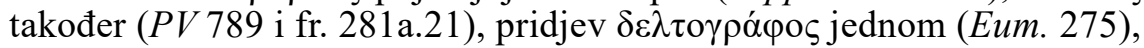
kao i glagol $\delta \varepsilon \lambda \tau o ́ o \mu \alpha \iota ~(S u p p .179)$. Na $\pi i ́ v \alpha \xi$ nailazimo triput (Supp.

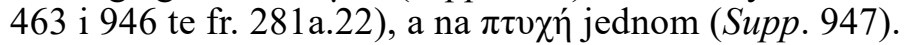

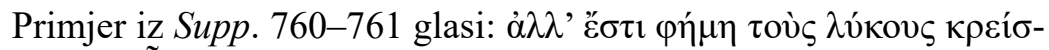

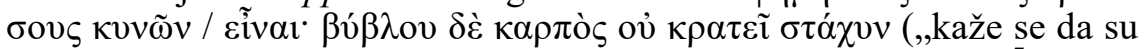
vukovi od pasa / jači; plod papirusa ne pobjeđuje kukuruz"). ${ }^{7}$ Očito, $\beta \tilde{\beta} \beta \lambda$ o se koristi u botaničkom smislu i ne odnosi se na prerađeni oblik papirusa (potencijalni nositelj zapisa). Nasuprot tome, u Supp. 946-947

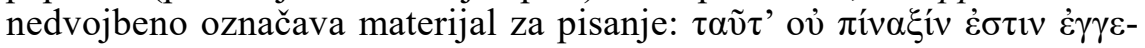

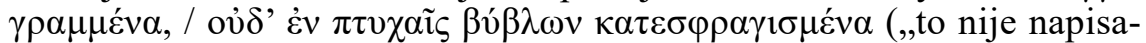
no na pločicama, / niti zapečaćeno na stranicama/svitcima papirusa").

analizu tragedija. Također, u oba spomenuta rada broj pretraživanih (stoga i pronađenih) termina znatno je manji nego u ovom radu.

${ }^{3}$ Pri pretrazi tragedija i fragmenata korišteni su program Diogenes i online izdanje baze tekstova $T L G$, dostupno na: http://stephanus.tlg.uci.edu/, pristup tijekom ožujka 2020.

${ }^{4} \mathrm{Za}$ tekst očuvanih Eshilovih tragedija korištena su izdanja West, 2012a-c i West, 2013a-d, a za fragmente Radt, 1985.

${ }_{6}^{5}$ Analiza upotrebe pratit će ovaj redoslijed.

${ }^{6}$ Kratice naslova drama (svih autora) preuzete su iz OCD (Oxford Classical Dictionary), dostupno na: https://oxfordre.com/classics/page/abbreviation-list/, pristup tijekom ožujka 2020.

${ }^{7}$ Prijevodi grčkih citata su naši vlastiti. 
Svi derivati korijena $\delta \varepsilon \lambda \tau$ - odnose se na pločice za pisanje. Prome-

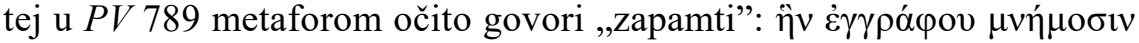
$\delta \varepsilon \dot{\lambda} \tau \tau o r \varsigma$ $\varphi \rho \varepsilon v \tilde{\omega} v$ („koje (sc. lutanje) si zapiši na pločice uma koje pam-

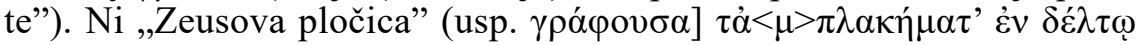
$\Delta$ ó́[s, tj. „Zapisujući prijestupe na Zeusovoj pločici”) iz fr. 281 a.21 ne bi trebala biti zamišljena kao fizički predmet na koji se zapisuju ljudski prijestupi. Slično tomu, u Eum. 275 Had ,sve promatra umom koji zapi-

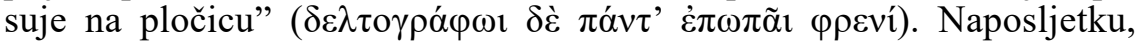

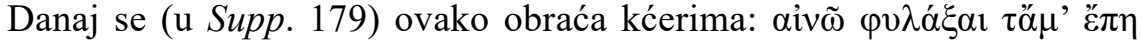
$\delta \varepsilon \lambda \tau o v \mu \varepsilon ́ v \alpha \varsigma$ (,preporučujem vam da čuvate moje riječi zapisujući ih sebi na pločice"). Kćeri nemaju ništa u rukama; spomen je metaforički (značenje: pamćenje).

Eshil upotrebljava $\pi$ ív $\alpha \xi$ isključivo za oznaku pločice, npr. u Supp.

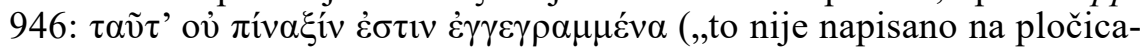
ma”). Drugi primjer iz iste drame (463) odnosi se na oslikane votivne

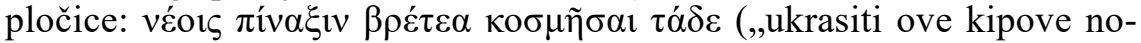

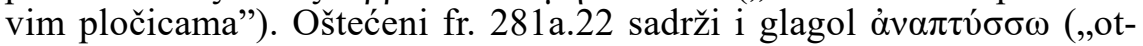
varati"), što otklanja sumnju o nekakvom drugom značenju imenice $\pi i v \alpha \xi$.

\subsection{Derivati od $\gamma \rho \alpha \varphi-$}

Imenica $\gamma \rho \alpha ́ \mu \mu \alpha$ pojavljuje se šest puta ( $P V$ 460, Sept. 434, 468,

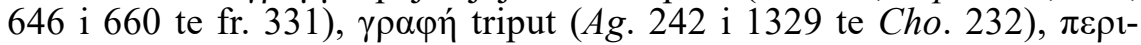

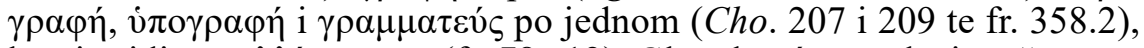

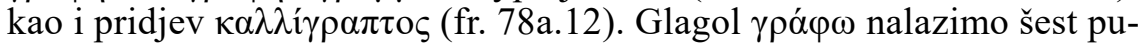
ta bez prefiksa (Ag. 801, Cho. 450 i 451, Eum. 50 te Supp. 709 i 991), a

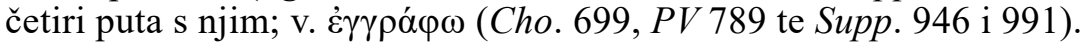

Pet od šest pojava imenice $\gamma \rho \alpha ́ \mu \mu \alpha$ je u množini, a upućuju ili na slova ili na poruku. Sintagmu „spajanje slova” susrećemo dvaput: u $P V$

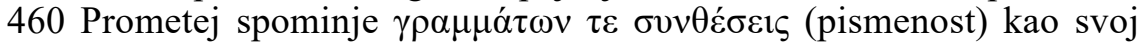
poklon čovječanstvu, dok primjer iz Sept. 468 naglašava poruku koja se

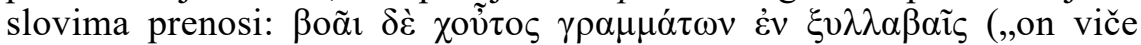
spojevima slova"). U ostalim primjerima $\gamma \rho \alpha ́ \mu \mu \alpha$ je sintaktički nepove-

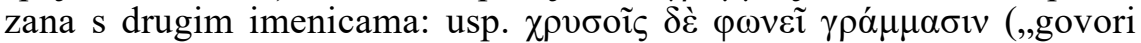

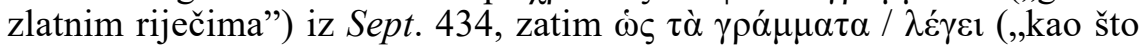

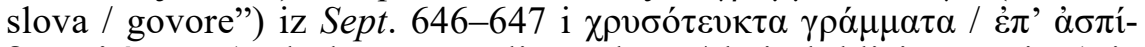
$\delta$ oऽ $\varphi \lambda u ́ o v \tau \alpha$ (,od zlata napravljena slova / koja brbljaju na štitu”) iz Sept. 660-661. Jedino je u fr. $331 \gamma \rho \alpha ́ \alpha \mu \alpha$ u jednini, ali ona stoji za

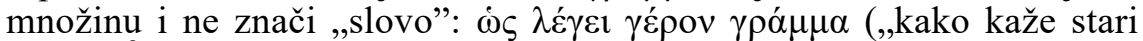
zapis"). ${ }^{8}$ Uočavamo da zapis može biti i personificiran i ,govoriti" (,zlatnim riječima” u Sept. 434 i „,skupovima slova” u Sept. 468), a dvaput ,govore” sama slova (Sept. 646-647 i fr. 331).

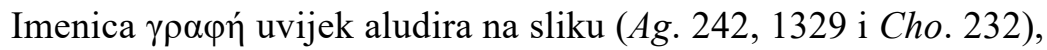

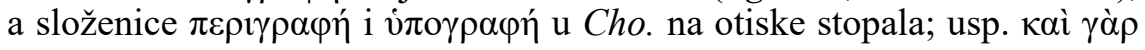

${ }^{8}$ Usp. prijevod „old writing” u Ceccarelli 2013: 199. 


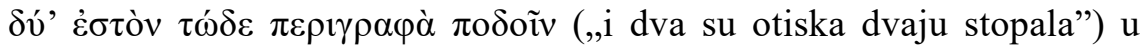

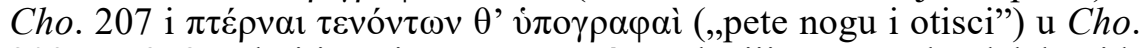
209. Fr. 358 sadrži imenicu $\gamma \rho \alpha \mu \mu \alpha \tau \varepsilon v ́ \varsigma$ u aluziji na staračku dalekovid-

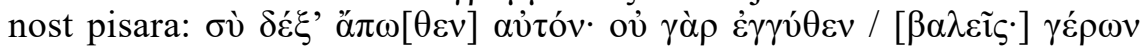

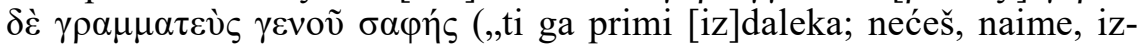
bliza / [pogoditi;] budi kao precizan stari pisar"). Naposljetku, pridjev

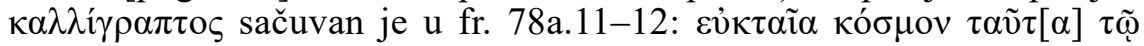

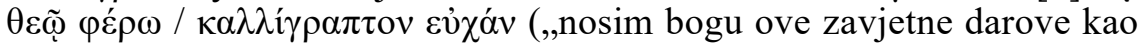
ures, / (kao) našminkanu molitvu"). Spomenute zavjetne darove neki tumače kao pločice s naslikanim satirima, no autori rada smatraju da je prije riječ o oslikanim glumačkim maskama. ${ }^{9}$

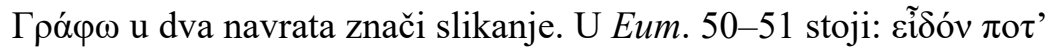

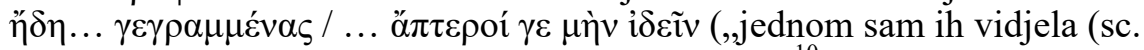

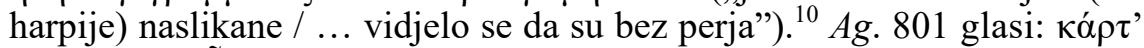

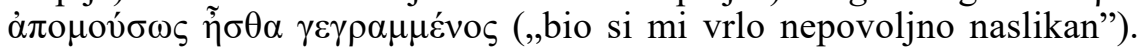
Skloni smo slikovnome shvaćanju, a značenje bi bilo: ,učinilo mi se da

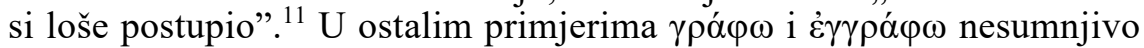
se odnose na pisanje. Korov odgovor $\gamma \rho \alpha ́$ á

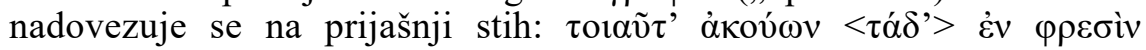
$<\gamma \rho \alpha ́ \varphi o v>$ (,slušajući te stvari, upiši ih sebi u um"). Značenje je, da-

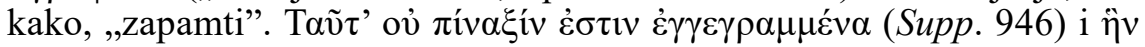

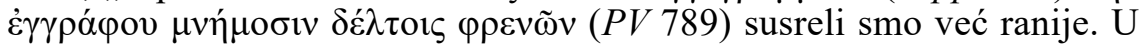

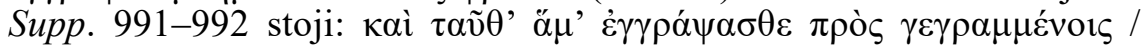

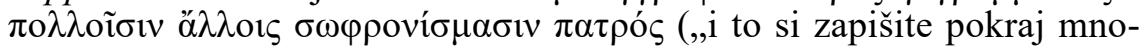
gih drugih zapisanih / očevih poduka"). To je usko povezano s aivõ $\varphi v-$

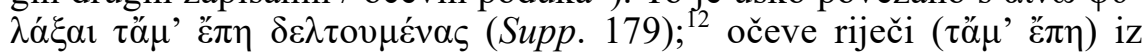
179. stiha očito su već upamćene (,zapisane”), a treba zapamtiti nove ( $\left.\tau \alpha \tilde{v} \theta^{\prime}\right)$. Na metaforički način treba shvatiti i Cho. 698-699: $v \tilde{v} v \delta$ '

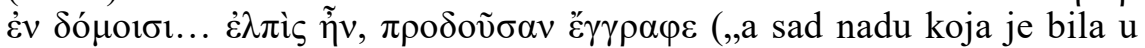
kući... zapiši kao izdajicu"). Posljednja dva primjera tiču se božice Dike. Onaj iz fr. 281a.21 već smo susreli (v. obradu termina $\delta \varepsilon ́ \lambda \tau o \varsigma)$, a u Supp. 707-709 spominje se poštovanje prema roditeljima: $\tau$ ó $\tau$ ' $\alpha \tilde{\tilde{z}} \tau \varepsilon-$

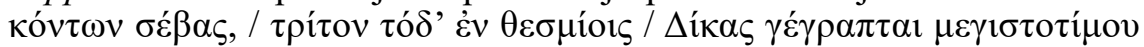
(, a poštovanje prema roditeljima / zapisano je kao treće među zakonima / prečasne Dike"). Radi se o metaforičkom zapisu. ${ }^{13}$

\subsection{Derivati od $\dot{\varepsilon} \pi \iota \sigma \tau \varepsilon \lambda \lambda$ -}

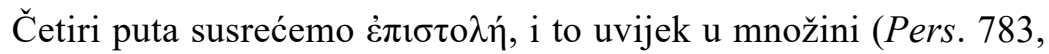

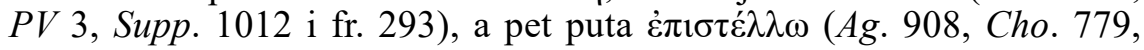
Eum. 205 i 743 te Sept. 1012).

\footnotetext{
${ }^{9}$ Popis zagovornika oba stajališta v. u Marconi, 2009: 12.

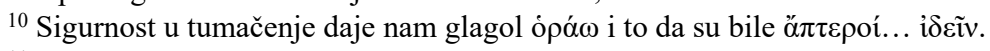

${ }^{11}$ Usp. Liddell i Scott, 1940: s. v. $\dot{\alpha} \pi$ ó

${ }^{12}$ Smisaona poveznica stihova preuzeta je od Ceccarelli, 2013: 194.

${ }^{13}$ Tako i Ceccarelli, 2013: 194.
} 


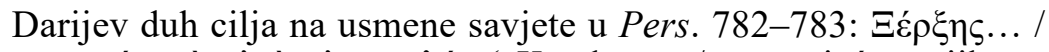

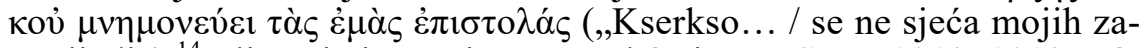
povijedi"). ${ }^{14}$ Sličan je i Danajev govor kćerima u Supp. 1012-1013: $\mu$ ó-

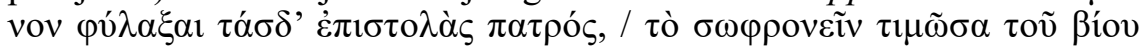
$\pi \lambda \varepsilon ́$ ov (,samo čuvaj ove očeve zapovijedi, / više cijeneći razum od života"), kao i Kratosovo obraćanje Hefestu (u PV 3-4): "Н

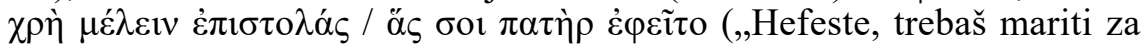
naredbe / koje ti je otac zapovjedio"). Iako nam nedostaje kontekst, dje-

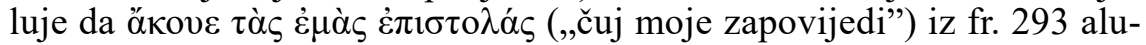
dira na isto.

I $\dot{\varepsilon} \pi \_\tau \varepsilon \dot{\lambda} \lambda \lambda \omega$ se koristi za usmene naredbe. U Ag. 908 pronalazi-

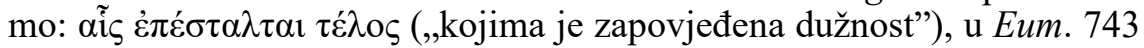

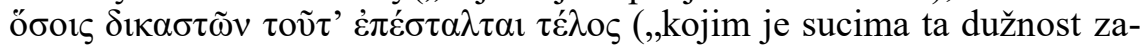

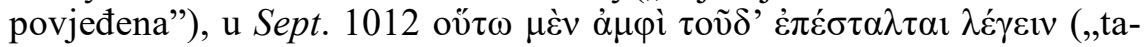
ko mi je zapovjeđeno da o njemu govorim"), a u Eum. 205 кaì $\pi \rho \circ \sigma-$

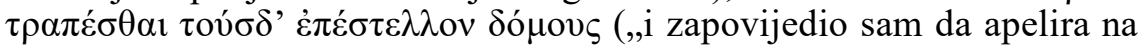
ovaj dom"). Samo u Cho. 779 susrećemo supstantivirani oblik participa:

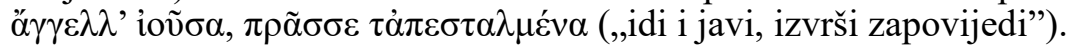

\subsection{Upotreba termina u Eshilovim dramama}

U Eshilovim dramama pronađena su 42 potencijalno relevantna termina. Metonimijskih termina je 10 (što je 24\%), 23 su derivata od

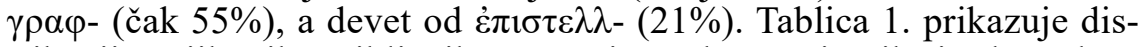
tribuciju njihovih približnih značenja, rekonstruiranih iz konteksta odlomaka u kojima se pojavljuju.

Tablica 1. Termini i značenja u Eshilovim dramama

\begin{tabular}{|c|c|c|c|}
\hline Termin & $\begin{array}{c}\text { Broj } \\
\text { primjera }\end{array}$ & Mjesto pojavljivanja & Značenje \\
\hline \multicolumn{4}{|c|}{ Metonimijski termini } \\
\hline \multirow{2}{*}{$\beta v ́ \beta \lambda o s$} & 1 & Supp. 761 & papirus (biljka) \\
\hline & 1 & Supp. 947 & papirus (materijal) \\
\hline$\delta \varepsilon ́ \lambda \tau O \varsigma$ & 2 & $P V 789$, fr. $281 \mathrm{a} .21$ & pločica (za pisanje) \\
\hline$\delta \varepsilon \lambda \tau о \gamma \rho \alpha ́ \varphi \circ$ & 1 & Eum. 275 & $\begin{array}{l}\text { koji zapisuje na } \\
\text { pločicu }\end{array}$ \\
\hline$\delta \varepsilon \lambda \tau o ́ o \mu \alpha \imath$ & 1 & Supp. 179 & $\begin{array}{l}\text { zapisivati sebi na } \\
\text { pločice }\end{array}$ \\
\hline$\pi i v \alpha \xi$ & 3 & $\begin{array}{l}\text { Supp. } 463 \text { i } 946, \text { fr. } \\
281 \mathrm{a} .22\end{array}$ & pločica \\
\hline$\pi \tau v \chi \eta ́$ & 1 & Supp. 947 & stranica \\
\hline
\end{tabular}

${ }^{14}$ Donekle iznenađuje što, iako su Perzijanci imali vrlo razvijen poštanski sustav (usp. Rosenmeyer, 2001: 24), u tragediji koja se njima bavi nema spomena pisanja ili slanja pisma. 


\begin{tabular}{|c|c|c|c|}
\hline \multicolumn{4}{|c|}{ Derivati od $\gamma \rho \alpha \varphi-$} \\
\hline \multirow[t]{2}{*}{$\gamma \rho \alpha ́ \mu \mu \alpha$} & 5 & $\begin{array}{c}P V 460, \text { Sept. } 434,468, \\
646 \text { i } 660\end{array}$ & slovo \\
\hline & 1 & fr. 331 & zapis \\
\hline 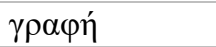 & 3 & Ag. 242 i 1329, Cho. 232 & slika \\
\hline$\pi \varepsilon \rho \iota \gamma \rho \alpha \varphi \eta ́$ & 1 & Cho. 207 & otisak stopala \\
\hline 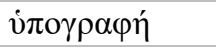 & 1 & Cho. 209 & otisak stopala \\
\hline$\gamma \rho \alpha \mu \mu \alpha \tau \varepsilon v ́ \varsigma$ & 1 & fr. 358.2 & tajnik/pisar \\
\hline$\kappa \alpha \lambda \lambda i^{\prime} \gamma \rho \alpha \pi \tau \sigma \varsigma$ & 1 & fr. $78 \mathrm{a} .12$ & lijepo obojan \\
\hline \multirow[b]{2}{*}{ 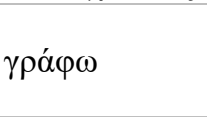 } & 2 & Ag. 801, Eum. 50 & slikati \\
\hline & 4 & $\begin{array}{c}\text { Cho. } 450 \text { i } 451, \text { Supp. } \\
709 \text { i } 991\end{array}$ & pisati \\
\hline 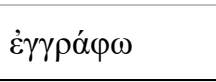 & 4 & $\begin{array}{l}\text { Cho. 699, PV 789, Supp. } \\
946 \text { i } 991\end{array}$ & pisati \\
\hline \multicolumn{4}{|c|}{ Derivati od $\dot{\varepsilon} \pi \iota \tau \varepsilon \lambda \lambda-$} \\
\hline$\dot{\varepsilon} \pi \iota \sigma \tau \Delta \lambda \eta ́$ & 4 & $\begin{array}{c}\text { Pers. 783, PV 3, Supp. } \\
\text { 1012, fr. } 293\end{array}$ & usmena zapovijed \\
\hline$\dot{\varepsilon} \pi 1 \sigma \tau \dot{\varepsilon} \lambda \lambda \omega$ & 5 & $\begin{array}{l}\text { Ag. 908, Cho. 779, Eum. } \\
205 \text { i 743, Sept. } \\
1012\end{array}$ & zapovijedati \\
\hline
\end{tabular}

Ukupno 19 primjera nevezano je uz pisanje: devet je usmenih zapovijedi, ${ }^{15}$ sedam poveznica sa slikanjem/bojanjem, ${ }^{16}$ dva otiska stopala, ${ }^{17}$ jedna aluzija na čvrstoću stabljike. ${ }^{18} \mathrm{Na}$ pločici spomenutoj u fr. 281a.22 može biti bilo što; primjer je nemoguće definirati. Preostala 22 termina (tj. 52\%) nedvojbeno su povezana uz pisanje; iz prve grupe potječe ih sedam, ${ }^{19}$ iz druge $15 .{ }^{20}$ Zanimljivo, jednako često aludira se na pravo i metaforičko pisanje, po 11 puta. ${ }^{21}$ Metaforičko ,zapisivanje” ekvivalent je pamćenju savjeta ili štovanju božanskih (moralnih) zakona, a postojeći „zapisi” su ili već upamćeni savjeti kojima treba dodati nove (v. Supp. 991-992) ili moralni zakoni koje su postavili (tobože u obliku liste napisali) sam Zeus, Had ili Dike (oni „zapisuju” i ljude koji se o zakone ogriješe). ${ }^{22}$ Cho. 698-699 odskače: ,zapisivanje” nečega označava definiranje osobina i stvaranje stava o njima.

\footnotetext{
${ }^{15}$ Ag. 908, Cho. 779, Eum. 205 i 743, Pers. 783, PV 3, Sept. 1012, Supp. 1012 i fr. 293.

${ }^{16}$ Ag. 242, 801 i 1329, Cho. 232, Eum. 50, Supp. 463 i fr. 78a.12.

${ }^{17}$ Cho. 207 i 209.

${ }_{18}$ Supp. 761.

${ }^{19}$ Eum. 275, Supp. 179, 946 i 947 (dva termina), PV 789 i fr. 281a.21.

${ }^{20}$ Cho. 450, 451, 699, PV 460 i 789, Sept. 434, 468, 660 i 646, Supp. 709, 946 i 991,
} fr. 281a.21, fr. 331 te fr. 358.2 .

${ }^{21}$ Pravo pisanje: PV 460, Sept. 434, 468, 646 i 660, Supp. 946 i 947 (po dva termina), fr. 331 te fr. 358.2. Metaforičko pisanje: Cho. 450, 451 i 699, Eum. 275, PV 789 (dva termina), Supp. 179, 709 i 991 (dva termina) te fr. 281a.21.

${ }_{22}$ Pisanje je povezano isključivo uz ljudsku sferu; bogovima ne treba jer su sveznajući, sve vide i sve pamte i bez te pomoćne vještine. Prometejev izum pisanja (usp. $P V$ ) 
Iako su potencijalno relevantni termini pronađeni u svim sačuvanim tragedijama, analiza pokazuje da su u Pers. i $\mathrm{Ag}$. posve nevezani za pisanje. ${ }^{23}$ Drame najbogatije aluzijama na pravo pisanje su Supp. i Sept. s po četiri primjera, a onim metaforičkim Supp. (također četiri primjera). $\mathrm{Ni}$ u sačuvanim dramama ni u fragmentima nema pisanih poruka ni pisama.

\section{Sofoklo}

Sofoklo 22 puta koristi termine koji mogu upućivati na pisanje ${ }^{24}$ a čini ih 10 različitih riječi (neke se pojavljuju više puta): $\delta \varepsilon ́ \lambda \tau o \zeta, \pi \tau v \chi \eta ́$,

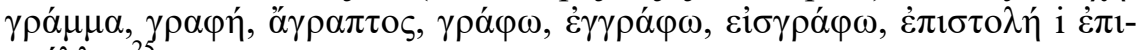
$\sigma \tau \dot{\varepsilon} \lambda \lambda \omega{ }^{25}$

\subsection{Metonimijski termini}

Iz ove grupe korištene su samo imenice $\delta \varepsilon ́ \lambda \tau o \varsigma$ (četiri puta: Trach.

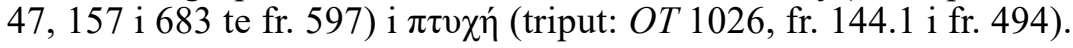

U Trach. 46-47 saznajemo da je Heraklo Dejaniri na odlasku osta-

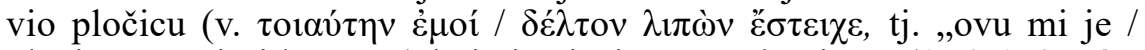
pločicu ostavio i krenuo") koja je ,ispisana znakovima” (156-158: $\tau$ ó $\tau$ '

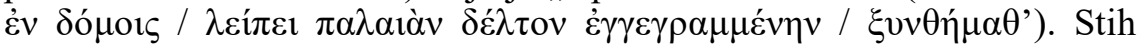
161. (i dalje) otkriva da je riječ o oporuci. Pri posljednjem spomenu pločice Dejanira objašnjava koru što treba učiniti s peplosom koji šalje Heraklu. Dejanira ne zna da šalje mužu otrov koji će ga ubiti; kentaur Nes lukavo ju je na samrti nagovorio da pokuša tim poklonom (tobože) vratiti muževu ljubav, a ona misli da je riječ o dobronamjernim savjetima i sjeća ih se „kao zapisa koji se teško skida s brončane pločice” (usp.

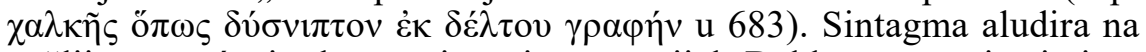
pažljivo pamćenje; bronca je trajan materijal. Dakle, u sva tri primjera iz Trach. riječ je o pravom pisanju, a u fr. 597 o metafori: $\theta$ oṽ $\delta$ ' $\dot{v} v \varphi \rho \varepsilon-$

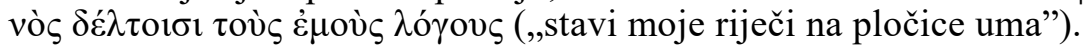

djeluje kao iznimka, ali on pismenost poklanja ljudima da im olakša živote, ne za komunikaciju s bogovima. Spomeni metaforičkog ,pisanja” bogova svojevrsna su poveznica dvaju svjetova - redovito aludiraju na trajnost božjih odredbi i nemogućnost skrivanja ljudskih prijestupa od njihovih očiju, a ograničeni su na Dike, koja s ljudima ima više kontakta, te (rjeđe) Zeusa i Hada. Usp. Ceccarelli, 2013: 192-193 i Jenkins, 2006: 84. (Sve rečeno vrijedi i u Sofoklovim dramama.)

${ }^{23}$ U najstarijoj sačuvanoj grčkoj tragediji, Pers., glasnik treba prepričati nevolje perzijske vojske, ali ne koristi se očekivani glagol govorenja, već stoji (u 254 i 294) $\alpha$ d $\alpha \pi \tau u ́-$ $\xi \alpha \iota$ / $\alpha v \alpha \pi \tau u ́ \xi \alpha \varsigma \pi \alpha ́ \theta$ os. Glagol znači „odmotati”, uz često podrazumijevanje odmotavanja

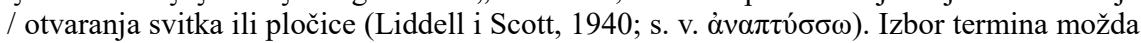
je aluzija na popis, tj. pisane dokumente općenito, ali to je nedokazivo. V. Ceccarelli, 2013: 184.

${ }^{24} \mathrm{Za}$ tekstove Sofoklovih sačuvanih tragedija korištena su kritička izdanja Dawe, 1982 te Dawe, 2013a-e, a za fragmente Radt, 1999.

${ }^{25}$ Analiza upotrebe pratit će ovaj redoslijed. 


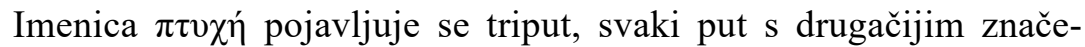

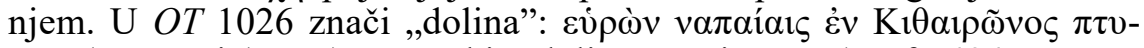

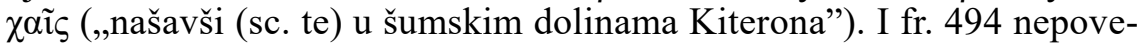

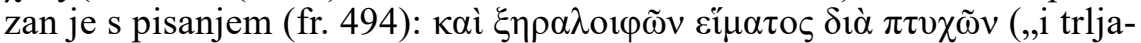
jući uljem kroz nabore odore"). No, fr. 144.1 odskače; pločica na sebi

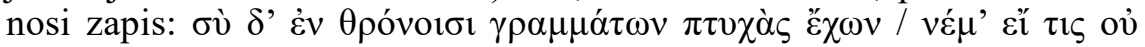

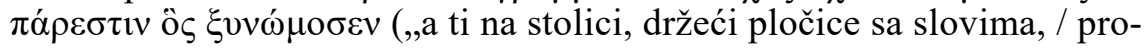
zivaj je li odsutan netko tko je dao zakletvu").

\subsection{Derivati od $\gamma \rho \alpha \varphi-$}

Triput pronalazimo $\gamma \rho \alpha \dot{\mu} \mu \mu \alpha$ (fr. 144.1, fr. 514 i fr. 784), a po jednom

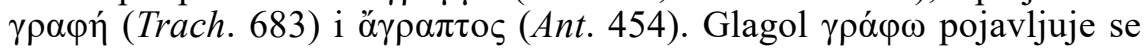

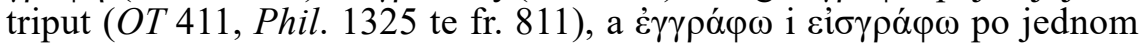
(Trach. 157 i 1167).

U već obrađenim primjerima, fr. 144.1 i Trach. 683, pojavljuju se i

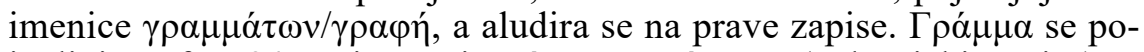

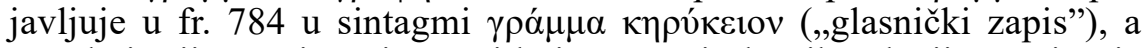
možda je riječ o pisanoj poruci koju prenosi glasnik. Aluzija na pisanje

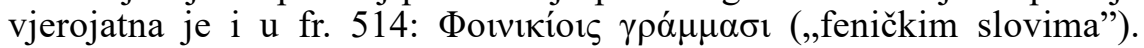

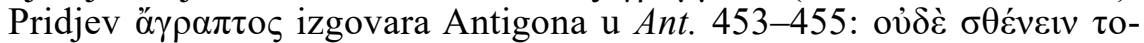

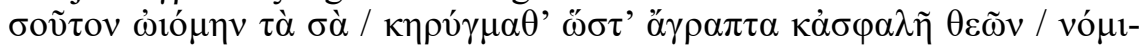

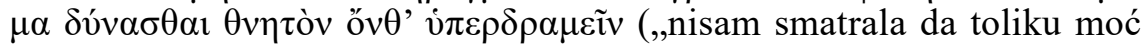
imaju tvoje / zapovijedi da nepisane i postojane božanske / zakone smrtnik može pregaziti”). Dakle, nepisani božji zakoni stavljeni su u opreku s pisanima - ljudskima; u ovim je stihovima jasno da se pisanje kao aktivnost ne povezuje uz božansku sferu.

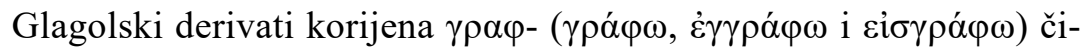
ne ukupno pet primjera. U OT 410-411 aludira se na ulogu ,potpisnika”

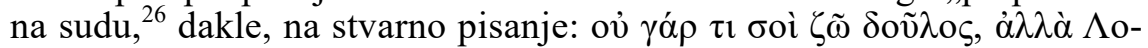

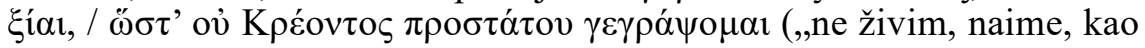
rob tebi, nego Loksiji, / tako da neću biti zapisan pod Kreontom kao zaštitnikom"). ${ }^{27}$ Sintagma iz Phil. 1325 poziv je na pamćenje izrečeno-

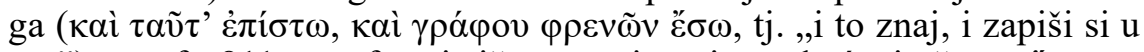
um"), a u fr. 811 metafora ističe nepovjerenje u obećanja žena: óркоv

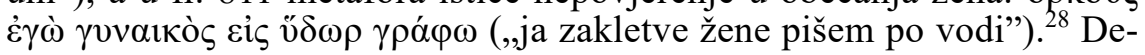

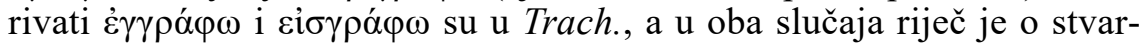

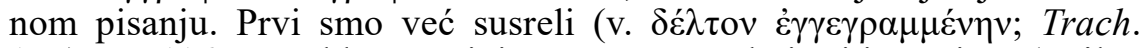
157), a u 1167 Heraklo spominje proročanstva koja si je zapisao (v. $\dot{\varepsilon} \xi \varepsilon-$

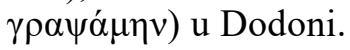

\footnotetext{
${ }^{26}$ Dawe, 1982: 134-135.

${ }^{27}$ Naravno, sveukupni je konačni smisao ulomka metaforički.

${ }^{28}$ Iako je sam pokušaj pisanja po vodi zamisliv, voda ustvari isključuje mogućnost stvarnog pisanja (ostavljanja traga), stoga primjer ipak pribrajamo među metaforičke. Usp. npr. ,pisanje u um” iz Phil. 1325: podudarno nedostaje materijal-nositelj sposoban održati (realno postojeći) trag čina zapisivanja.
} 


\subsection{Derivati od $\dot{\varepsilon} \pi \iota \tau \tau \varepsilon \lambda \lambda-$}

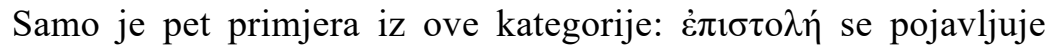
četiri puta (Aj. 781, OC 1601, Trach. 493 i fr. 128), a غ̇ंı (OT 106).

'E $\pi 1 \sigma \tau о \lambda \eta ́$ je svaki put u akuzativu množine. U $A j .781$ stoji: ó $\delta$ '

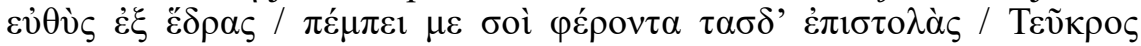

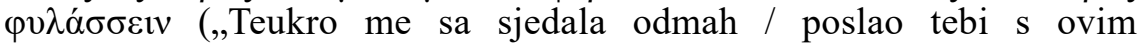
zapovijedima / da ih vršiš"). Zapovijed je usmena; ne spominje se predaja pločice s pisanim nalogom. Ista je situacija u $O C$ 1601-1602:

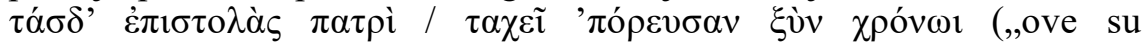
zapovijedi ocu / brzo izvršile"). U Trach. 492-493 pronalazimo: $\dot{\alpha} \lambda \lambda$ '

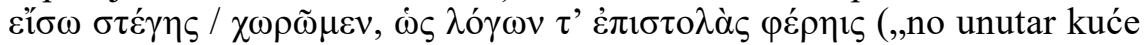
/ uđimo, kako bi prenio poruke (od) riječi”). Riječ je o usmenoj uputi u vezi prijenosa peplosa (v. 604-609). ${ }^{29}$ Posljednji ulomak (fr. 128) ne

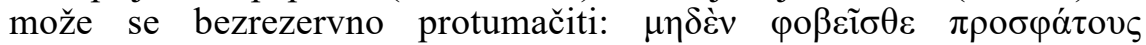

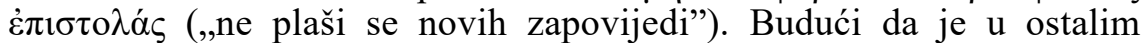
primjerima imenica aludirala na usmene zapovijedi, i ovdje to pretpostavljamo. Sličnu ulogu ima i $\dot{\varepsilon} \pi \_\tau \dot{\lambda} \lambda \lambda \omega$ u OT 106: vṽv

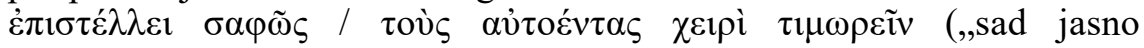
zapovijeda (sc. Apolon) / da se rukom kazne ubojice").

\subsection{Upotreba termina u Sofoklovim dramama}

Pronađena su 22 primjera. Sedam ih potječe iz prve grupe (32\%), 10 iz druge (45\%), a pet iz treće (23\%). Tablica 2. prikazuje distribuciju njihovih približnih značenja, rekonstruiranih iz konteksta odlomaka u kojima se pojavljuju.

Tablica 2. Termini i značenja u Sofoklovim dramama

\begin{tabular}{llll}
\hline \multicolumn{1}{c}{ Termin } & $\begin{array}{c}\text { Broj } \\
\text { primjera }\end{array}$ & Mjesto pojavljivanja & \multicolumn{1}{c}{ Značenje } \\
\hline Metonimijski termini & & \\
\hline$\delta \varepsilon ́ \lambda \tau o \varsigma$ & 4 & $\begin{array}{c}\text { Trach. } 47,157 \text { i } 683, \text { fr. } \\
597\end{array}$ & pločica (za pisanje) \\
& 1 & OT 1026 & $\begin{array}{l}\text { dolina } \\
\text { nabor } \\
\text { fr. } 494\end{array}$ \\
pločica (za pisanje)
\end{tabular}

${ }^{29}$ Tako i Jebb, 1892: 76. 


\begin{tabular}{|c|c|c|c|}
\hline$\gamma \rho \alpha ́ \varphi \omega$ & 3 & $\begin{array}{l}\text { OT 411, Phil. 1325, fr. } \\
811\end{array}$ & pisati \\
\hline 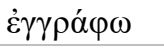 & 1 & Trach. 157 & pisati \\
\hline$\varepsilon i \sigma \gamma \rho \alpha ́ \varphi \omega$ & 1 & Trach. 1167 & pisati \\
\hline \multicolumn{4}{|c|}{ Derivati od $\dot{\varepsilon} \pi 1 \sigma \tau \varepsilon \lambda \lambda$ - } \\
\hline$\dot{\varepsilon} \pi 1 \sigma \tau 0 \lambda \eta ́$ & 4 & $\begin{array}{l}\text { Aj. } 781, \text { OC } 1601, \text { Trach } . \\
\text { 493, fr. } 128\end{array}$ & usmena zapovijed \\
\hline$\dot{\varepsilon} \pi 1 \sigma \tau \varepsilon ́ \lambda \lambda \omega$ & 1 & OT 106 & zapovijedati \\
\hline
\end{tabular}

U sedam slučajeva nema povezanosti s pisanjem: to su dva spomena

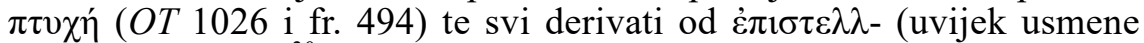
zapovijedi/upute). ${ }^{30}$ Dakle, 15 termina (čak $68 \%$ ) aludira na pisanje, a pet ih je iz prve te 10 iz druge kategorije. Na pravo pisanje odnosi se njih $12,{ }^{31}$ a na metaforičko tri (dvaput se aludira na pamćenje, a jednom na nepouzdanost žena). ${ }^{32}$

Iako su potencijalno relevantni termini pronađeni u svim sačuvanim dramama osim $E l$., analiza pokazuje da se samo u četiri tragedije aludira na pisanje (Ant., OT, Phil. i Trach.), od čega izrazito često u Trach. (čak šest puta). U Dejanirinom slanju peplosa uočene su sličnosti s epistolarnom komunikacijom: definirani su pošiljateljica i primatelj, a poput pisma, paket s ogrtačem ,putuje” te ima pečat. ${ }^{33}$ Ipak, pravih pisama u Sofoklovim dramama nema.

\section{Euripid}

Euripidove drame vrve terminima s potencijalom poveznice s pisanjem; ${ }^{34}$ pronađeno ih je 135 , a sačinjava ih 19 riječi (neke se pojavljuju

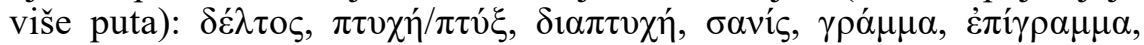
$\gamma \rho \alpha \mu \mu \eta ́, ~ \gamma \rho \alpha \varphi \eta ́, ~ \gamma \rho \alpha \varphi \varepsilon v ́ \varsigma, \mu \varepsilon \lambda \varepsilon \gamma \gamma \rho \alpha \varphi \eta ́ \varsigma, ~ \gamma \rho \alpha \pi \tau o ́ \varsigma, ~ \gamma \rho \alpha ́ \varphi \omega, \delta 1 \alpha \gamma \rho \alpha ́ \varphi \omega, \dot{\varepsilon} \gamma-$

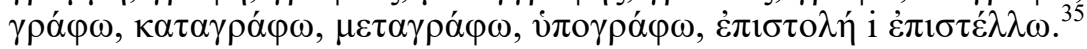

\subsection{Metonimijski termini}

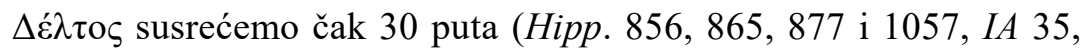
98, 109, 112, 116, 155, 307, 322, 798, 891 i 894, IT 584, 603, 615, 636,

${ }^{30}$ Aj. 781, OC 1601, OT 106, Trach. 493 i fr. 128.

${ }^{31}$ Ant. 454, OT 411, Trach. 47, $157 \mathrm{~s}$ dva termina, $683 \mathrm{~s}$ dva termina i 1167, fr. 144.1 s dva termina, fr. 514 te fr. 784 .

${ }^{32}$ Phil. 1325, fr. 597 i fr. 811.

${ }^{33}$ Rosenmeyer, 2001: 62 i Hajdarević, 2019: 4-5.

${ }^{34}$ Korištena su sljedeća izdanja: Basta Donzelli, 2013 (El.), Biehl, 2013 (Tro.), Daitz, 2013 (Hec.), Diggle, 1981 (HF, IT i Supp.), Diggle, 1984 (Andr.), Diggle, 1994 (Hel. i Or.), Garzya, 2011a (Alc.), Garzya, 2011b (Heracl.), Gunther, 2018 (Ion), Günther, 2010 (IA), Kopff, 2018 (Bacch.), Mastronarde, 2013 (Phoen.) i Stockert, 2013 (Hipp.). Fragmenti su navedeni prema Kannicht, 2004.

${ }^{35}$ Analiza upotrebe pratit će ovaj redoslijed. 
$641,667,727,733,756,760,787$ i 791, fr. 369.6 , fr. 506.2 i fr. 578.9$){ }^{36}$

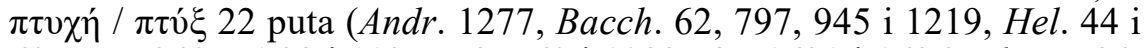
605, HF 240, IA 98 i 112, IT 9, 760 i 1082, Or. 1631 i 1636, Phoen. 84, Supp. 212, 757 i 979, fr. 228a.20, fr. 506.2 i fr. 779.7), složenicu $\delta 1 \alpha \pi \tau v-$

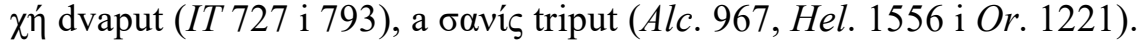

Fedrino klevetničko pismo prvi se put spominje u Hip. 856-857: है $\alpha$

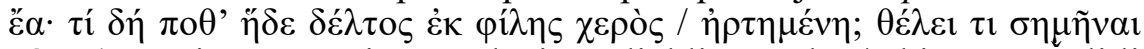
véov (,Jao, jao! Zašto je ova pločica o ljubljenu ruku / obješena? Zeli li pokazati/reći nešto novo?"). Tezej otvara pismo uz riječi (864-865):

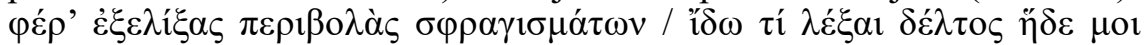
$\theta \varepsilon ́ \lambda \varepsilon ı$ (,hajde da otvorim nanos pečata / i da vidim što mi želi ova pločica reći”). Sadržaj ga šokira i govori korifeju da „pločica viče, viče ne-

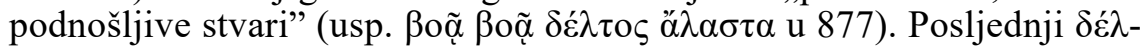

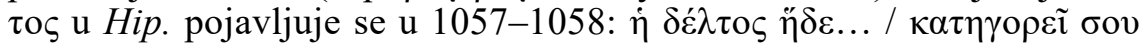
$\pi ı \sigma \tau \alpha$ („ova pločica... / govori protiv tebe uvjerljivo”). Pismo je fizički prisutno na sceni, a u tri navrata je personificirano i ,progovara”. Dok je sadržaj Tezeju još nepoznat, „sadrži znakove” ili „govori” (856), a kasnije „viče” (877) i „optužuje” (1057).

U IA $\delta \varepsilon ́ \lambda \tau o \varsigma$ se pojavljuje 11 puta. Nakon što je pismom pozvao Ifigeniju u Aulidu, Agamemnon želi drugim spriječiti njezin dolazak. ${ }^{37} \mathrm{Pi}-$

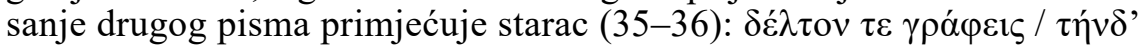

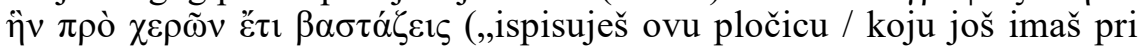
ruci”). Agamemnon spominje pismo koje je već poslao supruzi (98-99):

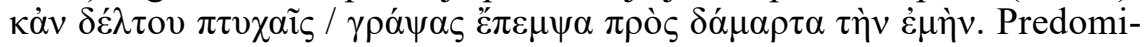
slio se, napisao drugo (107-109) i reći će ,što pločica na stranicama

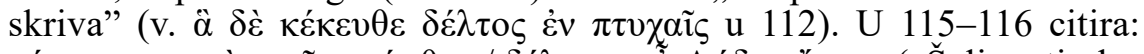

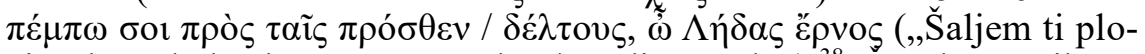
čice kao dodatak uz one prošle, / Ledino čedo"). ${ }^{38}$ Cetrdeset stihova

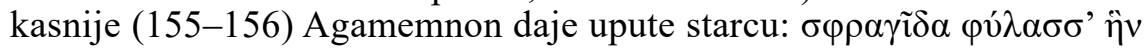

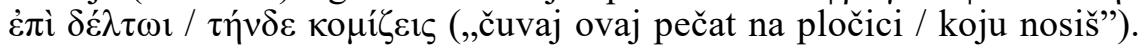
Nakon što Menelaj zaplijeni pločicu, starac mu govori (307): oủ $\chi \rho \tilde{\eta} v$

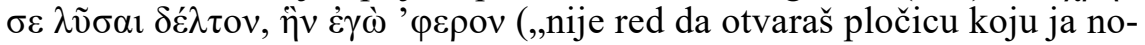

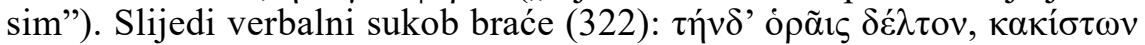

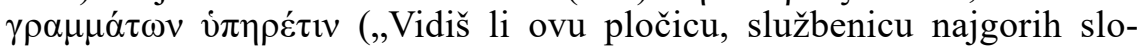
va?"). Pločica se opet spominje tek kada Klitemnestra stigne u Aulidu

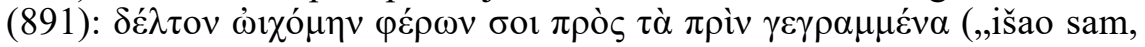
noseći ti pločicu (sc. koja se nadovezuje) na prijašnje zapisane riječi”).

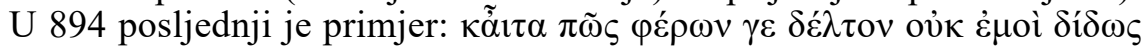
$\lambda \alpha \beta \varepsilon i ̃ v$ („I zašto, onda, iako mi nosiš pločicu, ne daš da je uzmem?”).

${ }^{36}$ Uočavamo da 27 primjera potječe iz tri sačuvane tragedije: Hip. (četiri), IA (11) i IT (12), a preostala tri iz fragmenata.

${ }^{37}$ Grci trebaju žrtvovati Ifigeniju kako bi im bio omogućen polazak prema Troji.

${ }^{38}$ Uočavamo dodatni spomen (prvoga) pisma, ostvaren bez upotrebe nekoga od pre-

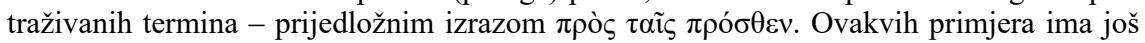

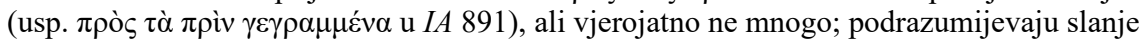
više pisama za redom, što nije čest slučaj u fabulama (osim $I A$ ). Potraga za njima znatno bi produžila planirano istraživanje. 
Jedino u IA 798-799 nailazimo na spomen pločice koja nije ni jedno od

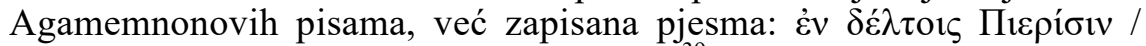
$\mu \tilde{0} \theta$ or (,na pijeridskim pločicama / priče"). ${ }^{39}$

U IT Ifigenija je svećenica u Tauridi i zadatak joj je žrtvovati strance, stoga su Orest i Pilad u smrtnoj opasnosti kad se tamo pojave. Ifigenija želi kontaktirati obitelj; u 582-584 spominje pločicu s napisanom

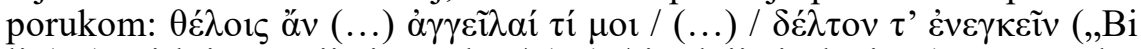
li (...) mi htio prenijeti poruku / (...) / i odnijeti pločicu”). Orest odo-

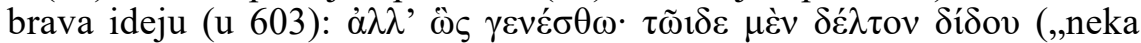
bude tako, ovome daj pločicu"). Ifigenija u 614-615 odlučuje poslati

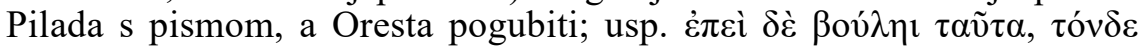

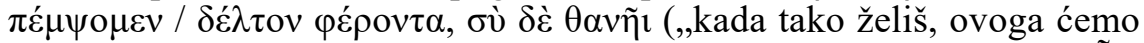
poslati / s pločicom, a ti ćeš umrijeti”). Odlazi po pločicu (v. $\alpha \lambda \lambda$ ' $\varepsilon \tilde{i} \mu \mathrm{r}$

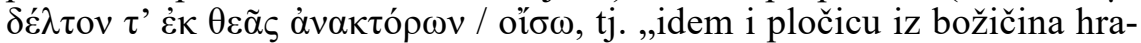
ma / donijet ću" u 636-637). U 641-642 zamišlja kako pločica Orestu

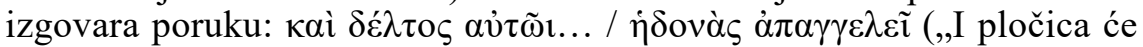

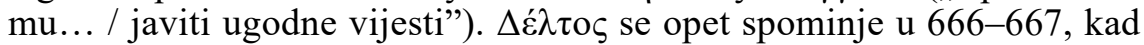
Orest i Pilad zaključuju da je Ifigenija jamačno Argivka, jer ,inače ne bi

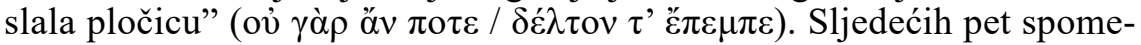

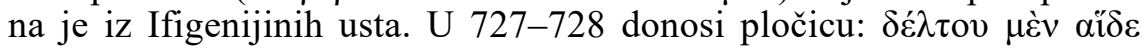

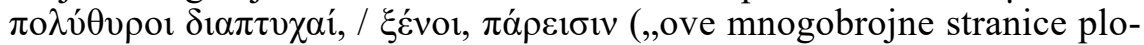
čice, / stranci, tu su”). U 733 izražava strah da bi ,onaj koji bi trebao

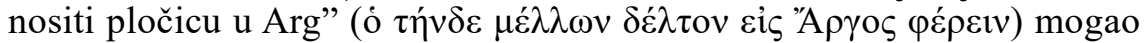
zanemariti dogovor ili da bi ,pločica u valu... / mogla nestati” (usp. $\chi \dot{\eta}$

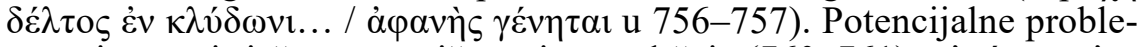

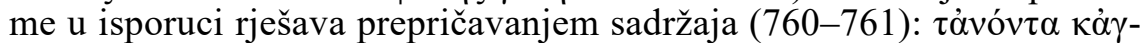

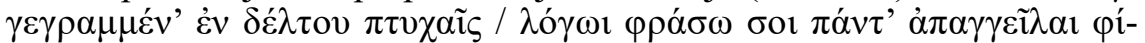
$\lambda$ ors („Ono prisutno i zapisano na stranicama pločice / riječju ću ti reći sve, da javiš ljubljenima”). U 787 zaključuje: „to je ono što je zapisano

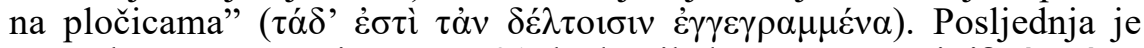

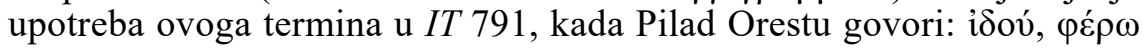

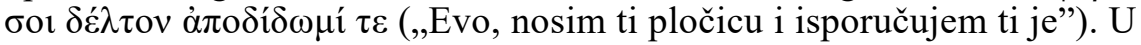
ovoj tragediji $\delta \varepsilon ́ \lambda \tau o \varsigma$ se svaki put odnosi na istu pločicu (u $I A$ su dvije).

U fr. 369.6-7 pločice se personificiraju tako što im se daje glas, no,

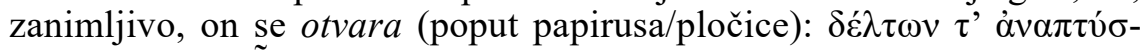

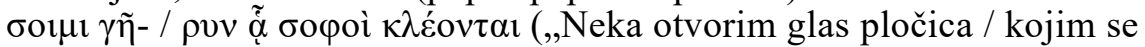
slave mudri”). Fr. 506.1-3 sadrži (već viđen) motiv Zeusove pločice:

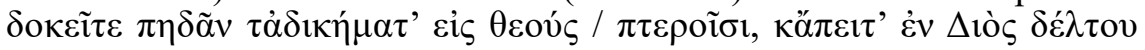

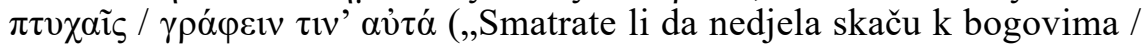
uz pomoć krila, i da ih zatim na stranicama Zeusove pločice / netko za-

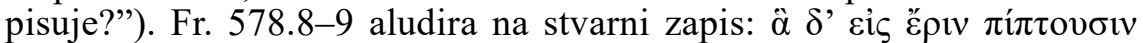

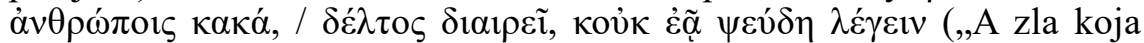
ljudima izazivaju svađu / pločica raspoznaje, i ne dopušta govoriti laži”).

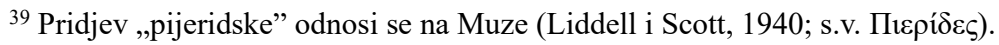


Termin $\pi \tau v \chi \eta ́ / \pi \tau v ́ \xi$ pronalazimo 22 puta, a četiri primjera uz $\delta \varepsilon ́ \lambda-$ $\tau o \varsigma$ sačinjavaju frazu jasno povezanu s pisanjem. Dvaput je nalazimo u

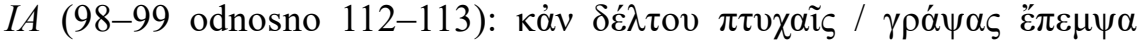

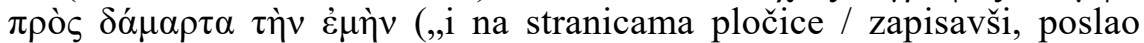

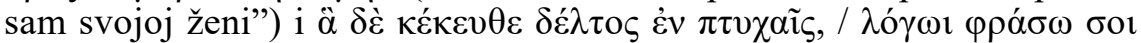

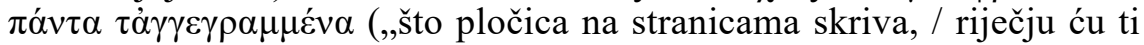

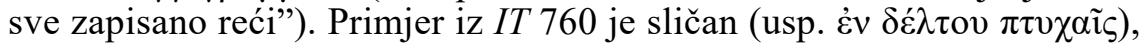

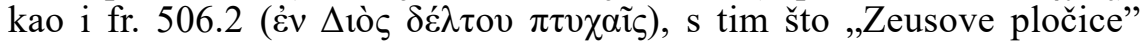
imaju metaforičko značenje. Preostalih 18 primjera s pisanjem su nepo-

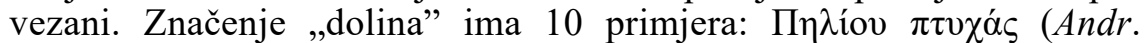

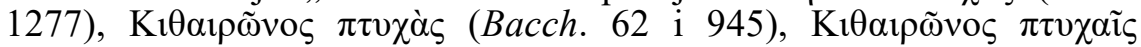

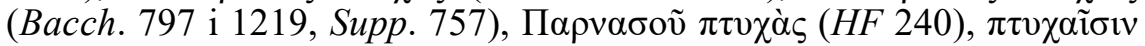

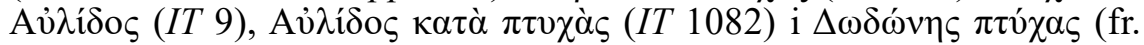
228a.20). Isti termin šest puta znači „,nebo”, odnosno „predio”: v. $\pi \tau v-$

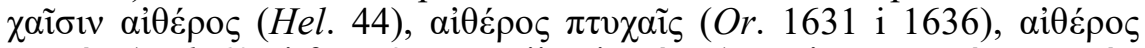

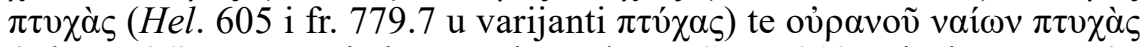
(Phoen. 84). Uočeno je i značenje „nabor”; Supp. 212 opisuje organe (v.

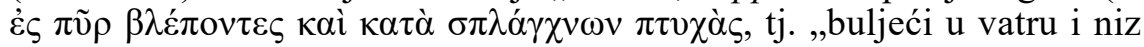

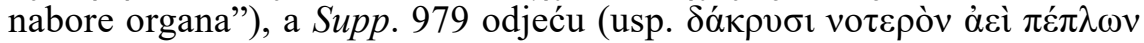

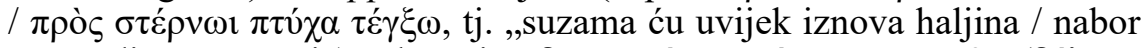

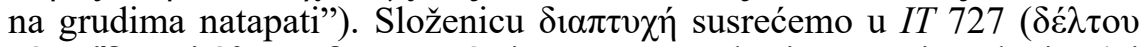

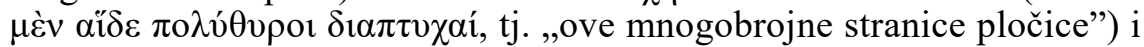

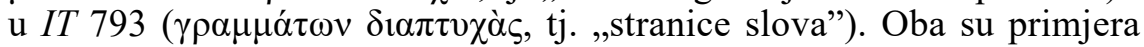
povezana s pisanjem.

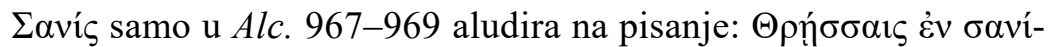

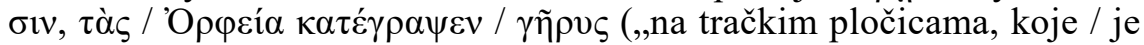
ispisao orfejski / govor"). U Hel. 1555-1556 stoji: $\tau \alpha u ́ \rho \varepsilon 10 \varsigma \delta \dot{\varepsilon} \pi$ ov̀ /

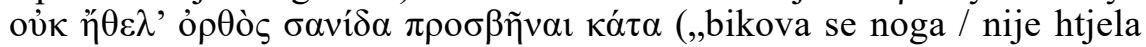
pravo uspeti na palubu"). Zadnji primjer je u Or. 1220-1221: $\varphi \theta \tilde{\eta} 1 .$. / ì

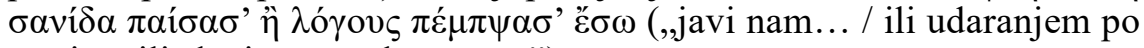
vratima ili slanjem poruke unutra").

\subsection{Derivati od $\gamma \rho \alpha \varphi-$}

Imenica $\gamma \rho \alpha ́ \mu \mu \alpha$ pojavljuje se 15 puta (Hipp. 387, 954 i 1253, IA 37, 118 i 322, Ion 1146, IT 594, 745, 764 i 793, fr. 382.1, fr. 578.3, fr.

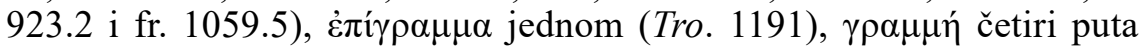
(El. 956, fr. 169 te fr. 382.5 i 11), a $\gamma \rho \alpha \varphi$ ń 14 puta (Hec. 866, Hipp. 451, 879, 1005 i 1311, IA 363, Ion 271, IT 735 i 762, Phoen. 129 i 1135, Tro. 687, fr. 618.2 i fr. 1059.5). Po jednom se pojavljuju imenica $\gamma \rho \alpha \varphi \varepsilon v ́ s$

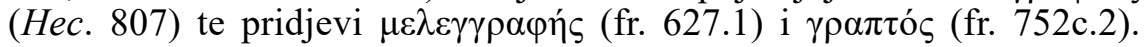

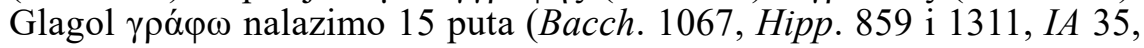
99 i 891, Ion 443, IT 585, Phoen. 574, Supp. 433, Tro. 1189, fr. 378.2,

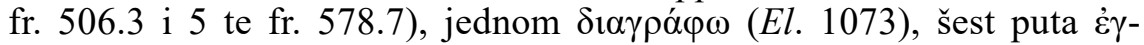

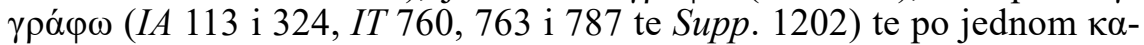

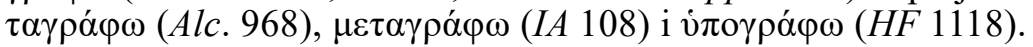


Гра́ $\mu \mu \alpha$ se triput pojavljuje u Hip. i upućuje na pisanje, ali ne i na Fedrino pismo. U 385-387 očito se radi o aluziji na pisanje: $\alpha i \delta \omega \varsigma \varsigma \tau \varepsilon$.

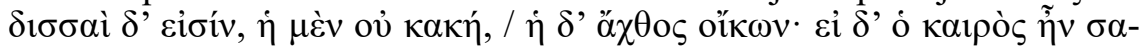

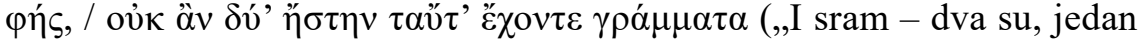
nije loš, / a drugi je muka domova. Da je prikladnost sigurna, / ne bi bila dva s istim slovima"). Slično je i u 953-954; Tezej Hipolita naziva

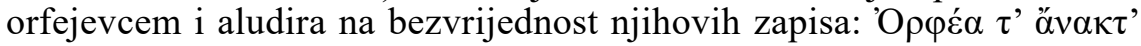

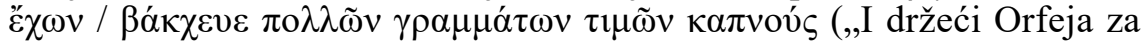
gospodara / luduj, poštujući isparavanje mnogih slova"). U 1252-1254 glasnik kaže da ne bi vjerovao da je Hipolit loš „,̌ak ni da se objesi sav ženski rod, i da tko na Idi sve pločice od borova drva ispuni slovima"

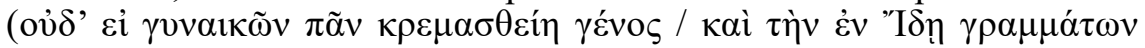

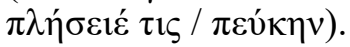

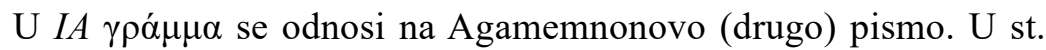
37 starac opisuje kako Agamemnon ,ponovno briše (dosl. muti) ista slo-

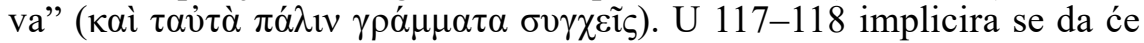

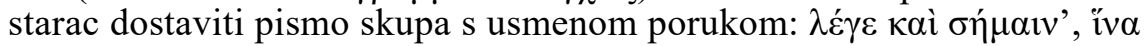

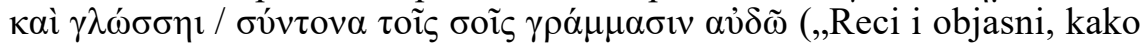
bih jezikom / rekao sukladno tvojim slovima"). Naposljetku, kada je

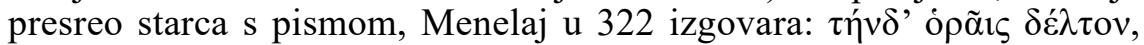

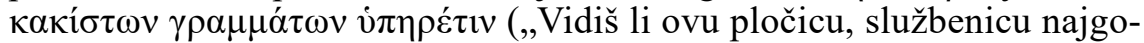
rih slova?"). Svi primjeri odnose se na fizički prisutnu pločicu koja je prvo u Agamemnonovim, zatim starčevim i naposljetku Menelajevim rukama.

I u IT $\gamma \rho \alpha ́ \alpha \mu \alpha$ se uvijek odnosi na (Ifigenijino) pismo. Promotri-

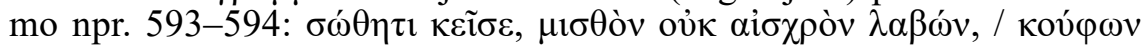

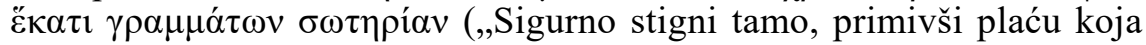
nije sramotna, / spasenje, pomoću lakih slova"). Pilad obećava da će

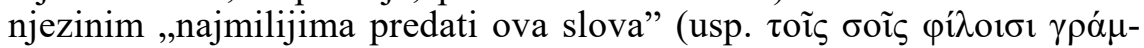

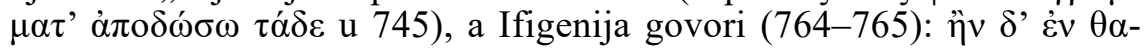

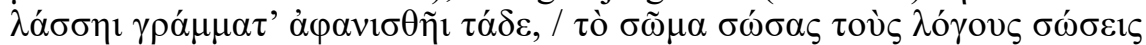
غ̇uoí („Ako u moru nestanu ova slova, / spasivši (sc. svoje) tijelo spasit

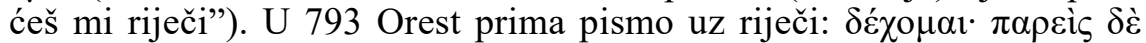

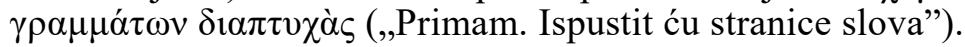

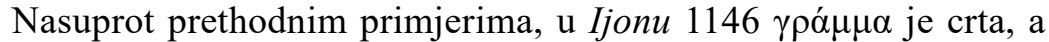

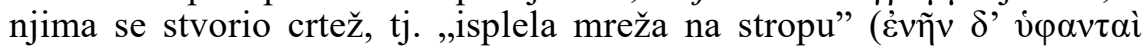

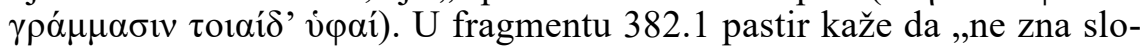

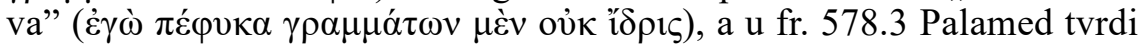

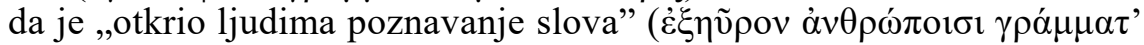

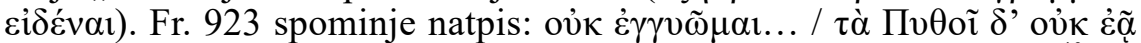
$\mu \varepsilon \gamma \rho \alpha ́ \mu \mu \alpha \tau \alpha$ („,neću jamčiti... / ne dopuštaju mi slova u Delfima”). ${ }^{40}$ Fr. 1059.5 odnosi se na crtež; tvrdi se da je pokvarenost žena zlo koje se ne

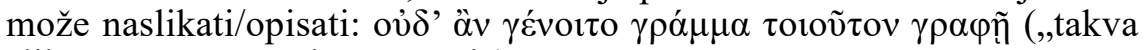
slika ne može crtanjem nastati”).

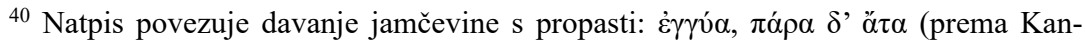
nicht, 2004: 926). 


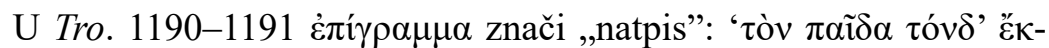

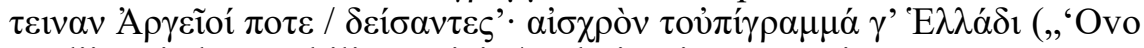
su dijete jednom ubili Argejci, / pobojavši se'; natpis na sramotu Grčkoj").

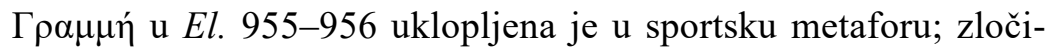
nac ne smije smatrati da je pobijedio ,prije nego dođe blizu / (sc. ciljne)

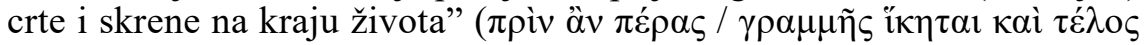

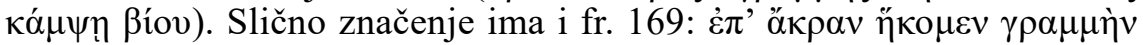
$\kappa \alpha \kappa \tilde{\omega} v$ („,došli smo do krajnje crte zala”). Zadnja su dva primjera iz već viđenog fr. 382 i odnose se na pisanje: nepismeni pastir opisuje izgled slova Tezejeva imena $(\Theta, H, \Sigma$, E, Y i $\Sigma)$ :

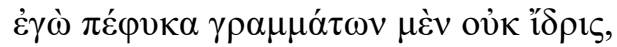

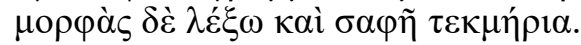

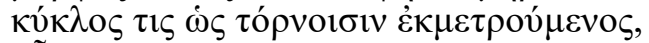

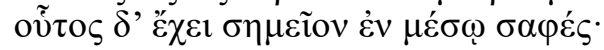

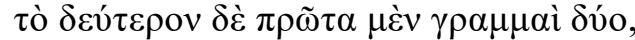

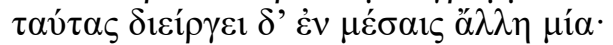

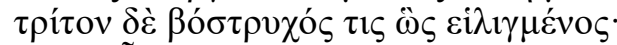

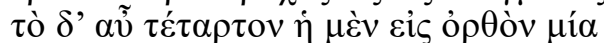

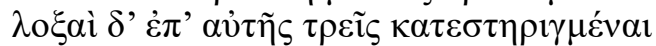

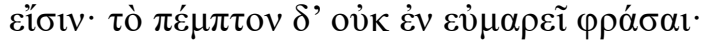

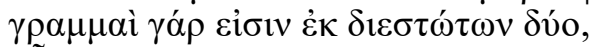

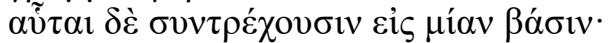

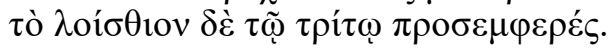

(,Ja po prirodi ne znam slova, / no razabrat ću oblike i sigurne znakove. / Neki krug kao da je izmjeren šestarima, / i ima jasan znak u sredini. / Drugi su znak, prvo, dvije crte, / koje jedna druga odjeljuju u sredini. / Treće je neki zavoj, ovako zavrnut, / a četvrto je ravna crta, / i na njoj su pričvršćene tri okomite. / Peto nije lako opisati, / naime, dvije su crte, iz dvije odvojene točke, / a spajaju se u jednu bazu. / Posljednje je nalik na treće.")

Imenicom $\gamma \rho \alpha \varphi \eta ́$ u Hec. 866-867 aludira se na pisane zakone: $\grave{\eta}$

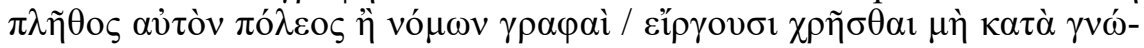

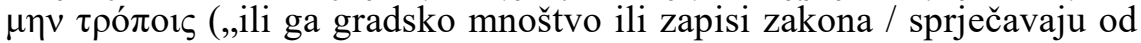
djelovanja po naumu"). U Hip. 451-452 riječ je o pjesništvu: ő $\sigma o 1 \mu \grave{\varepsilon} v$

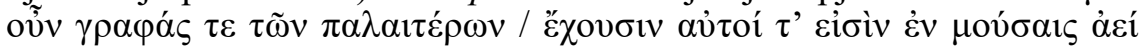
(„koji imaju zapise starijih, / i koji su i sami uvijek u pjesmama”). Tezej u 879-880 sadržaj Fedrina pisma doživljava kao melodiju, što je neobi-

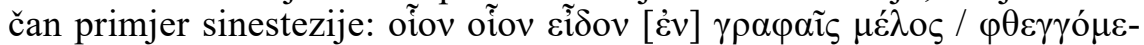
vov $\tau \lambda \alpha \mu_{\mu} \omega v$ (,kakvu sam, kakvu, jadan, vidio melodiju / kako pjeva u zapisima"). U idućem slučaju (1004-1005) Hipolit spominje svoju čistoću i da mu je (sc. seksualni), ,čin nepoznat i da o njemu ne govori /

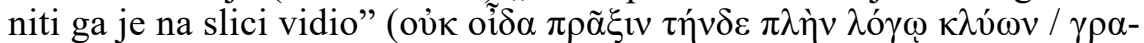
$\varphi \tilde{n} \tau \varepsilon \lambda \varepsilon v ́ \sigma \sigma \omega v)$. Naposljetku, Artemida za Fedrino pismo govori da je

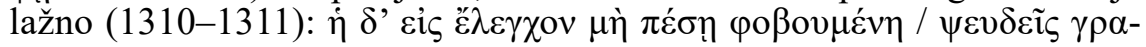
$\varphi \grave{\varsigma} \varsigma \check{\varepsilon} \gamma \rho \alpha \psi \varepsilon$ (,ona je, plašeći se da ne upadne u sramotu, / napisala lažne 
zapise"). Dakle, u Hip. dvaput se ovim terminom cilja na Fedrino pismo, a dva spomena nepovezana su s radnjom (zapis i slika).

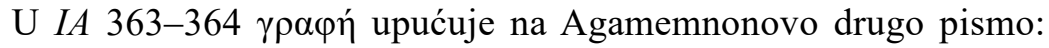

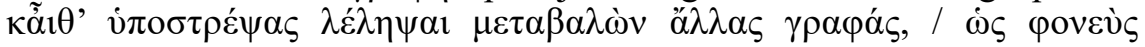

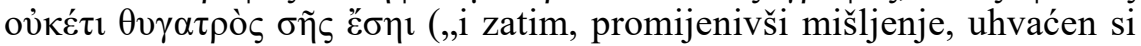
kako si izmijenio (sc. pismo, poruku) u druge zapise, / da ne budeš više ubojica svoje kćeri”). U Ion 271 nailazimo na poveznicu sa slikom: $\delta$ í-

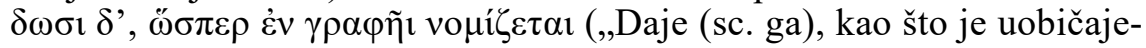
no na slici").

U oba primjera iz IT aludira se na Ifigenijino pismo. U 735-736

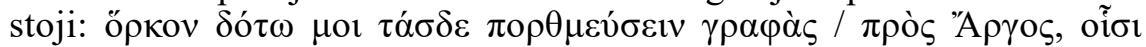

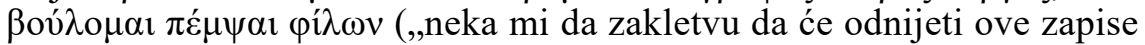
/ u Arg, onim ljubljenima kojima ih želim poslati”). U 762-763 pismo je

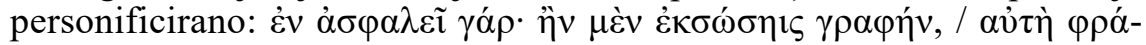

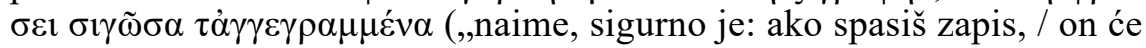
sam, šuteći, pokazati ono što je na njemu zapisano").

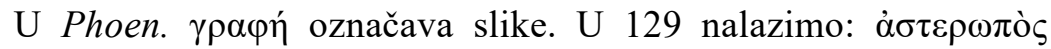

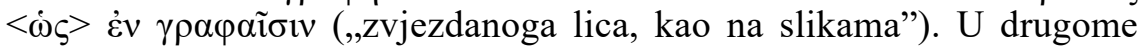

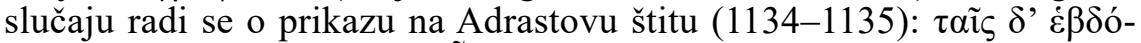

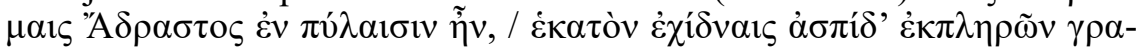
$\varphi \tilde{n}$ (,Adrast je na sedmim vratima, / ispunjajući štit stotinom zmija po-

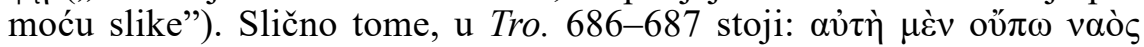

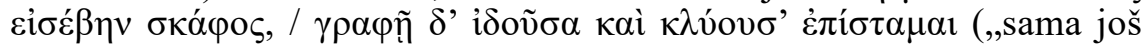
nisam kročila na palubu broda, / no znam (sc. ponešto o tome), jer sam vidjela na slici i slušala (sc. o tome)"). U fragmentima se termin koristi

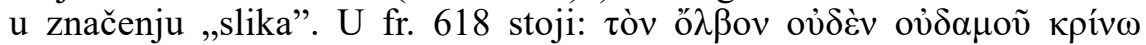

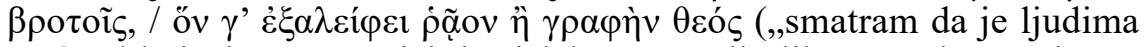
sreća, / koju bog može izbrisati lakše nego li sliku, apsolutno ništav-

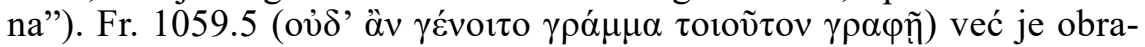
đen $($ v. $\gamma \rho \alpha ́ \mu \mu \alpha)$.

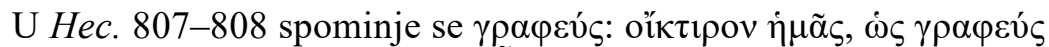

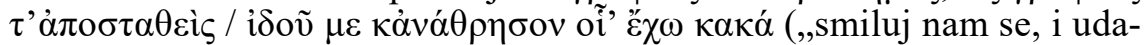
ljivši se kao slikar / pogledaj me i vidi zla koja trpim”). Osim uobičajenog značenja „slikar", ${ }^{41}$ Ceccarelli ostavlja mogućnost da se aludira na

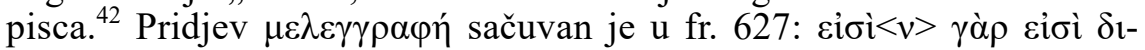

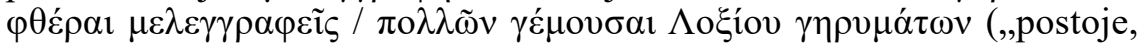
naime, postoje kože ispisane pjesmama, / ispunjene mnogim Loksijinim zvucima"). Ovdje bi se moglo raditi o Apolonovim proročkim odgovorima zapisanima u heksametru. ${ }^{43}$ Pridjev $\gamma \rho \alpha \pi \tau o ́ \varsigma$ iz fr. $752 \mathrm{c}$ odnosi se na

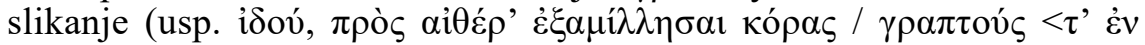

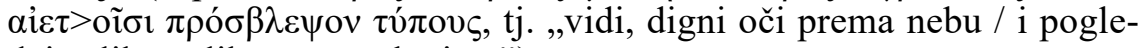
daj oslikane likove na zabatima").

\footnotetext{
${ }^{41}$ Liddell i Scott, 1940: s. v. $\gamma \rho \alpha \varphi \varepsilon v ́ \varsigma$ (spomen Euripidovih drama).

42 Usp. Ceccarelli, 2013: 209.

${ }^{43}$ Ceccarelli, 2013: 218.
} 
Glagol $\gamma \rho \alpha ́ \alpha \omega$ pronađen je 15 puta. Prvi je primjer iz Bach.

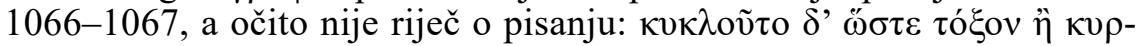

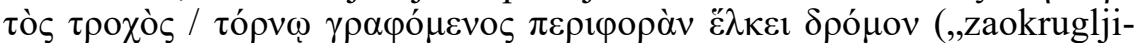
valo se poput luka ili kao što se vrti grbavo kolo, / koje tokarski nož urezuje tijekom vrtnje"). U Hip. 858-859 Tezej izgovara kada ugleda

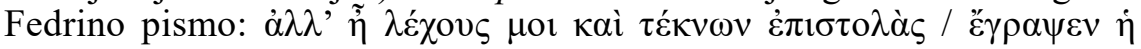

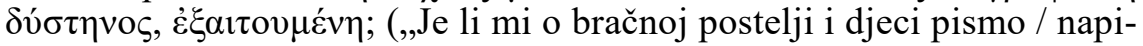
sala, jadnica, moleći me?"). Kasnije Artemida objašnjava da je Fedra

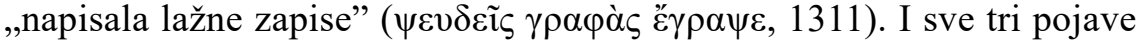
termina u $I A$ značenjski su povezane s pisanjem (Agamemnonovih) pi-

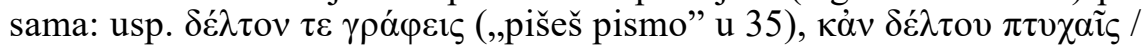

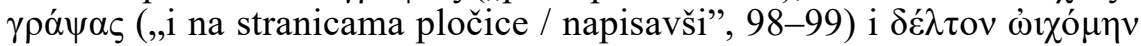

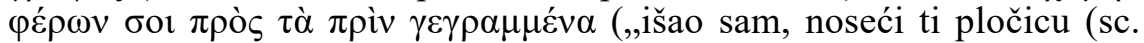
koja se nadovezuje) na prijašnje zapisane riječi”, 891). Primjer iz Ijona

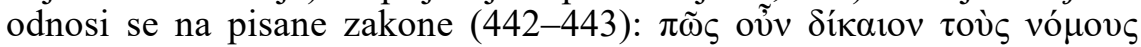

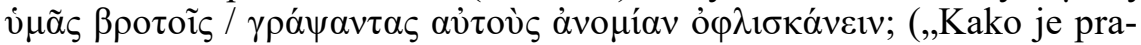
vedno da ste vi, premda ste smrtnicima zakone / zapisali, sami okrivljeni za bezakonje?"). U IT glagol se pojavljuje samo jednom, a povezan je

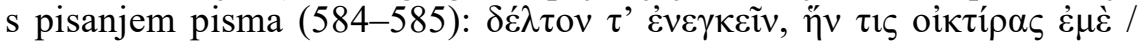

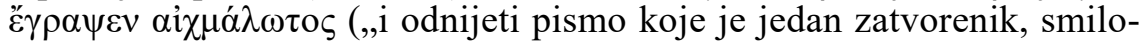
vavši mi se / napisao"). Preostala tri primjera iz očuvanih tragedija od-

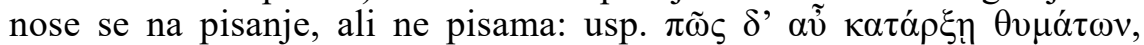

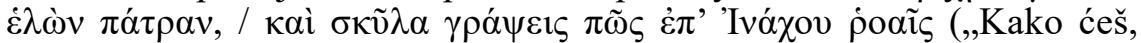
kad zauzmeš domovinu, započeti sa žrtvama / i kako ćeš uz obalu Inaha zapisati svoje ime na ratnome plijenu?") iz Phoen. 573-574, zatim $\gamma \varepsilon-$

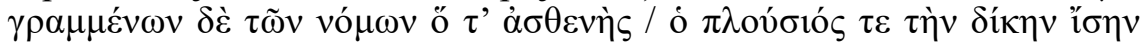
¿̌ $\chi \varepsilon 1$ (,,kad su zakoni zapisani, i nemoćan / i bogat imaju jednako pra-

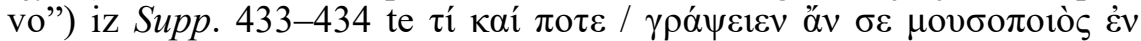

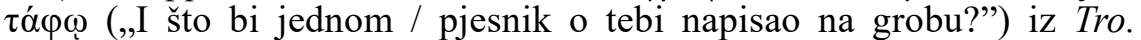
1188-1189. Naposljetku, četiri su relevantna fragmentarna citata. Prvi

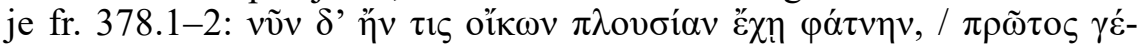

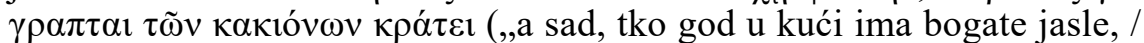
zapisan je kao prvi prema mišljenju lošijih"). Гદ́ $\gamma \rho \alpha \pi \tau \alpha \iota$ aludira da bi se hipotetska osoba zapravo smatrala prvom. U fr. 506. dva su primjera:

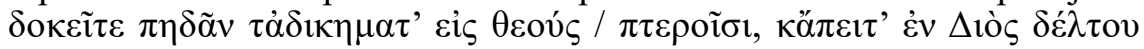

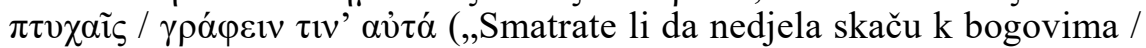
krilima, i da ih zatim na stranicama Zeusove pločice / netko zapisuje" u

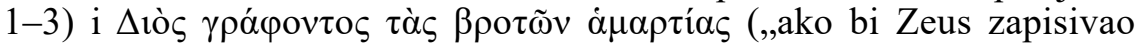
grijehe smrtnika" u 5). Posljednji je primjer iz Pal. 6-7, a riječ je o opo-

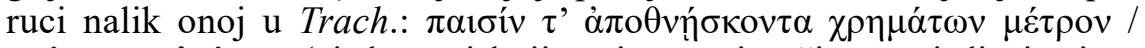
$\gamma \rho \alpha ́ \psi \alpha \nu \tau \alpha \Lambda \varepsilon^{i} i \pi \varepsilon$ (, (,i da onaj koji umire, zapisavši, ostavi djeci mjeru stvari").

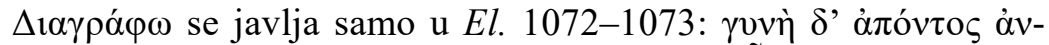

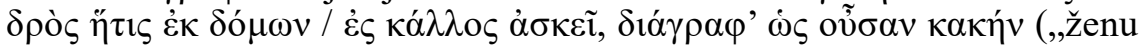
koja se dok je muž izvan kuće / sređuje prekriži kao lošu”). Zamišlja se da je ženino ime na nekakvom popisu i da se ono treba prekrižiti - 


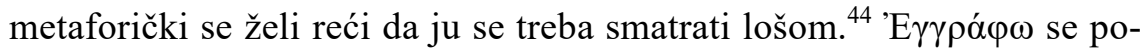

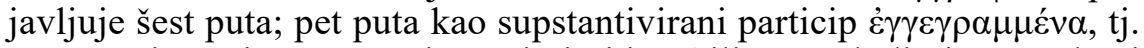
„ono što je zapisano", a svi su primjeri iz IA ili IT te aludiraju na sadržaj

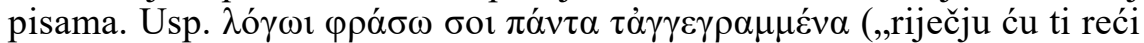

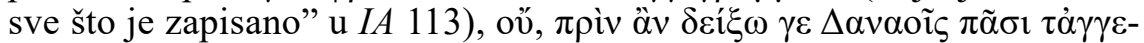
$\gamma \rho \alpha \mu \mu \varepsilon ́ v \alpha$ (,,ne prije nego li pokažem svim Danajcima ono što je zapisa-

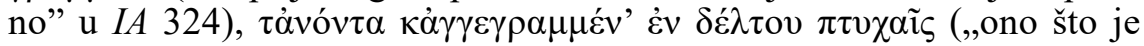

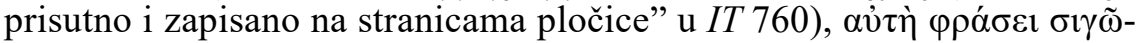
$\sigma \alpha \tau \dot{\alpha} \gamma \gamma \varepsilon \gamma \rho \alpha \mu \mu \varepsilon ́ v \alpha$ (,ona će šuteći pokazati ono što je zapisano" u IT

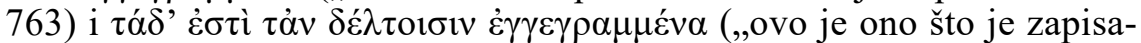
no na pločicama" u IT 787). Posljednji primjer u finitnom je obliku

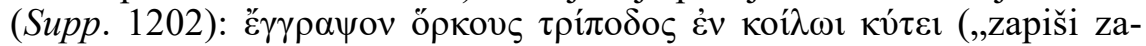
kletve na zakrivljenoj šupljini tripoda"). Složenice $\kappa \alpha \tau \alpha \gamma \rho \alpha ́(\varphi \omega, \mu \varepsilon \tau \alpha-$

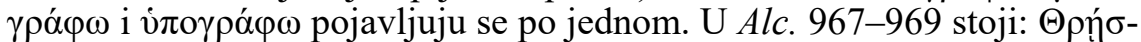

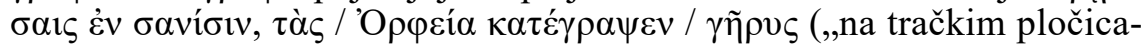

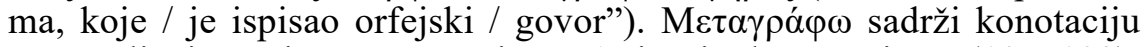
prepravljanja napisanoga, a to je u $I A$ pisanje drugog pisma (107-109):

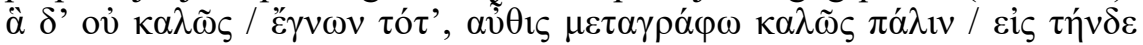
$\delta \varepsilon \dot{\lambda} \tau$ Tov (,što nisam dobro / zamislio tada, sad iznova ispravno pišem /

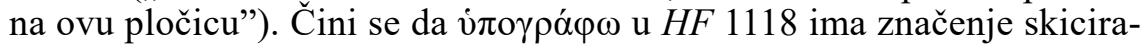

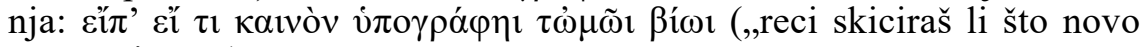
mome životu").

\subsection{Derivati od $\dot{\varepsilon} \pi \iota \sigma \tau \varepsilon \lambda \lambda-$}

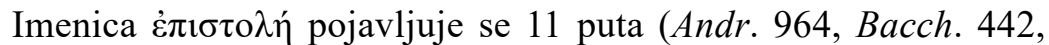
Hel. 1649, Hipp. 858, IA 111 i 314 te IT 589, 732, 767, 786 i 1446), a glagol غ̇ं $1 \sigma \tau \dot{\varepsilon} \lambda \lambda \omega$ pet puta (El. 333, Heracl. 938, IT 770, Phoen. 863 i Tro. 1149).

'E $\pi 1 \sigma \tau 0 \lambda \eta ́$ se u prva tri primjera koristi u značenju usmene zapo-

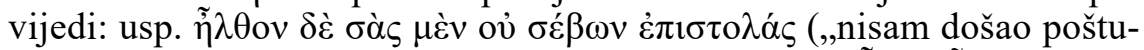

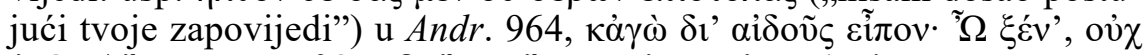

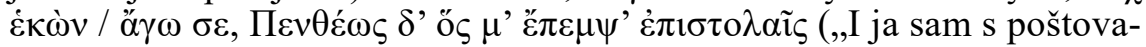
njem rekao: 'Stranče, ne vodim / te rado, nego po zapovijedima Penteja,

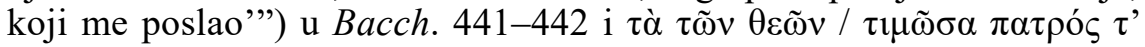

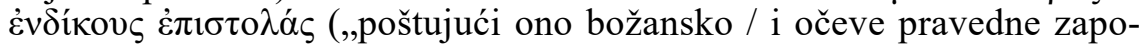

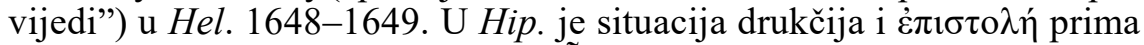

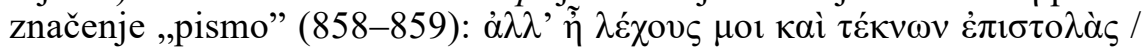

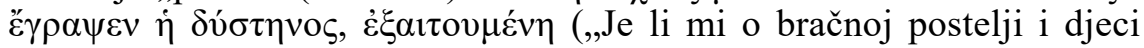

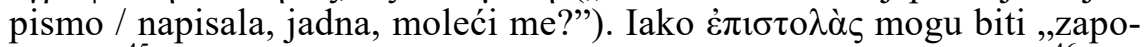
vijedi" ${ }^{45}$ Ceccarelli i Rosenmeyer preferiraju značenje ,pismo”; ${ }^{46}$ ali, čak i ako se misli na zapovijedi, one moraju biti napisane (v. Ě $\gamma \rho \alpha \psi \varepsilon v)$ ).

\footnotetext{
${ }^{44}$ Tako i Ceccarelli, 2013: 207 (bilj. 78). Primjer nećemo smatrati pisanjem.

${ }^{45}$ V. Liddell i Scott, 1940: s. v. غ̇ंıб

${ }^{46}$ Ceccarelli, 2013: 220, a Rosenmeyer, 2001: 88-89.
} 


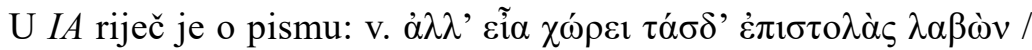

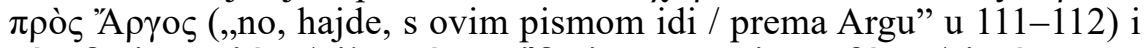

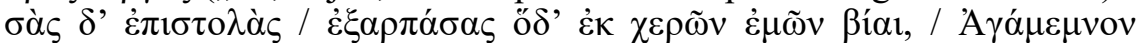
(,ovaj, zgrabivši / tvoje pismo silom iz mojih ruku, / Agamemnone”, 314-316). U IT ova se imenica koristi čak pet puta. U 588-590 غ̇лıбто-

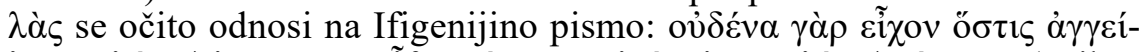

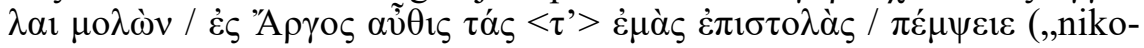
ga, naime, nisam imala tko bi prenio poruku stigavši / natrag u Arg, i tko bi moje pismo / prenio"). Sljedeći citat (731-733) malo je proble-

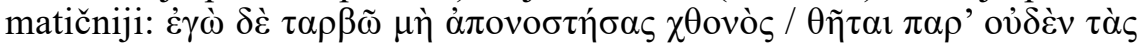

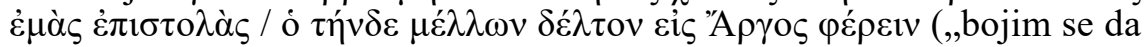
bi onaj koji bi trebao nositi pločicu u Arg, / napustivši ovu zemlju, / zanemario moje zapovijedi"). U 733. stihu spominje se pismo, a $\dot{\varepsilon} \pi 1 \sigma \tau 0 \lambda \alpha \grave{s}$ iz 732. stiha može se odnositi na sadržaj pisma ili na Ifigenijin zahtjev Piladu da to pismo prenese. Autori ovoga rada potonje smatraju točnim; zvuči zalihosno uzastopce aludirati na pismo dvama riječima (prvo na pločicu, zatim na tekst na njoj). ${ }^{47}$ Sljedeća dva citata odno-

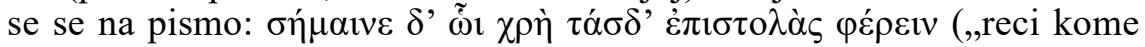

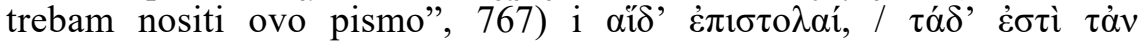
$\delta \varepsilon ́ \lambda \tau o l \sigma ı v ~ \varepsilon ̇ \gamma \gamma \varepsilon \gamma \rho \alpha \mu \mu \varepsilon ́ v \alpha$ (,ovo je pismo, / ovo je ono što je zapisano na pločicama", 786-787). Riječi u 1446 izgovara Atena i očito se radi o us-

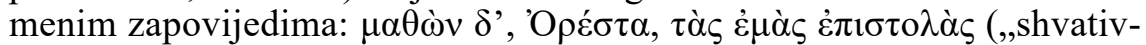
ši, Oreste, moje zapovijedi").

Glagol $\dot{\varepsilon} \pi \iota \tau \tau \dot{\varepsilon} \lambda \lambda \omega$ pronalazimo pet puta. Triput se koristi u kon-

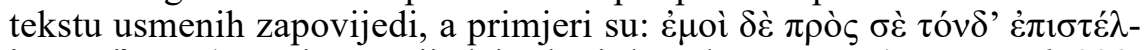

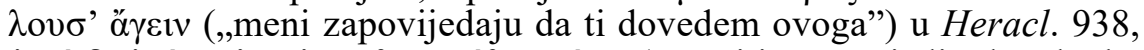

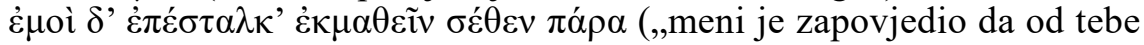

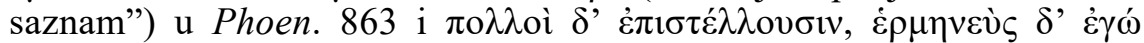
(,mnogi šalju poruku, a ja sam tumač”) u El. 333. Sukladno tome, participni oblik u Tro. 1149 ( $\tau \dot{\alpha} \pi \varepsilon \sigma \tau \alpha \lambda \mu \varepsilon ́ v \alpha)$ znači ,zapovijed”. Drugačije je

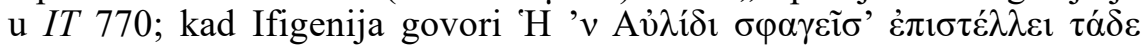
(„Ubijena u Aulidi šalje ovo”), misli na pismo, čiji sadržaj prepričava u nastavku odlomka.

\subsection{Upotreba termina u Euripidovim dramama}

Distribucija je ovakva: iz prve grupe potječe 57 primjera (42\%), iz druge $62(46 \%)$, a iz treće $16(12 \%)$. Tablica 3. prikazuje distribuciju njihovih približnih značenja, rekonstruiranih iz konteksta odlomaka u kojima se pojavljuju.

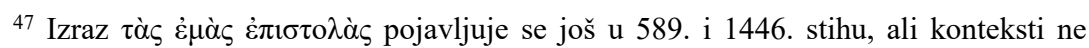
pomažu; u prvom slučaju odnosi se na pismo, u drugom na usmenu zapovijed. 
Tablica 3. Termini i značenja u Euripidovim dramama

\begin{tabular}{|c|c|c|c|}
\hline Termin & $\begin{array}{c}\text { Broj } \\
\text { primjera }\end{array}$ & Mjesto pojavljivanja & Značenje \\
\hline \multicolumn{4}{|c|}{ Metonimijski termini } \\
\hline 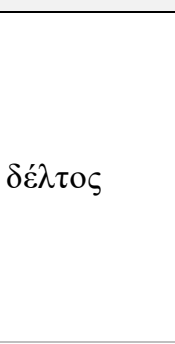 & 30 & $\begin{array}{c}\text { Hipp. } 856,865,877 \mathrm{i} \\
1057, I A 35,98, \\
109,112,116,155, \\
307,322,798,891 \mathrm{i} \\
894, I T 584,603, \\
615,636,641,667 \\
727,733,756,760 \\
787 \text { i } 791, \text { fr. } 369.6 \\
\text { fr. } 506.2, \text { fr. } 578.9\end{array}$ & pločica (za pisanje) \\
\hline \multirow{3}{*}{$\pi \tau v \chi \eta^{\prime} / \pi \tau v^{\prime} \xi$} & 4 & $\begin{array}{l}I A 98 \text { i } 112, I T 760, \text { fr. } \\
\quad 506.2\end{array}$ & stranica \\
\hline & 16 & $\begin{array}{l}\text { Andr. 1277, Bacch. } 62, \\
\text { 797, } 945 \text { i } 1219, \\
\text { Hel. } 44 \text { i } 605, H F \\
\text { 240, IT } 9 \text { i } 1082, \text { Or. } \\
\text { 1631 i } 1636, \text { Phoen. } \\
\text { 84, Supp. } 757, \text { fr. } \\
\text { 228a.20, fr. } 779.7\end{array}$ & dolina \\
\hline & 2 & Supp. 212 i 979 & nabor \\
\hline$\delta 1 \alpha \pi \tau v \chi \eta ́$ & 2 & $I T 727$ i 793 & stranica \\
\hline 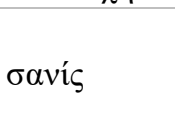 & $\begin{array}{l}1 \\
1 \\
1\end{array}$ & $\begin{array}{l}\text { Alc. } 967 \\
\text { Hel. } 1556 \\
\text { Or. } 1221\end{array}$ & $\begin{array}{l}\text { pločica (za pisanje) } \\
\text { paluba } \\
\text { vrata }\end{array}$ \\
\hline \multicolumn{4}{|c|}{ Derivati od $\gamma \rho \alpha \varphi-$} \\
\hline \multirow[t]{2}{*}{$\gamma \rho \alpha ́ \mu \mu \alpha$} & 13 & $\begin{array}{l}\text { Hipp. } 387,954 \text { i } 1253, \\
I A 37,118 \text { i } 322, I T \\
594,745,764 \text { i } 793, \\
\text { fr. } 382.1, \text { fr. } 578.3, \\
\text { fr. } 923.2\end{array}$ & slovo \\
\hline & 2 & Ion 1146, fr. 1059.5 & slika \\
\hline$\dot{\varepsilon} \pi^{\prime} \gamma \rho \alpha \mu \mu \alpha$ & 1 & Tro. 1191 & natpis \\
\hline$\gamma \rho \alpha \mu \mu \eta ́$ & $\begin{array}{l}2 \\
2\end{array}$ & $\begin{array}{l}\text { El. } 956, \text { fr. } 169 \\
\text { fr. } 382.5 \text { i } 11\end{array}$ & $\begin{array}{l}\text { crta } \\
\text { crta (u pisanju) }\end{array}$ \\
\hline \multirow[b]{2}{*}{$\gamma \rho \alpha \varphi \eta ́$} & 7 & $\begin{array}{l}\text { Hec. 866, Hipp. } 451, \\
879 \mathrm{i} 1311, I A 363, \\
I T 735 \mathrm{i} 762\end{array}$ & zapis \\
\hline & 7 & $\begin{array}{l}\text { Hipp. } 1005, \text { Ion } 271, \\
\text { Phoen. } 129 \text { i } 1135, \\
\text { Tro. } 687, \text { fr. } 618.2, \\
\text { fr. } 1059.5\end{array}$ & slika \\
\hline 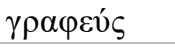 & 1 & Hec. 807 & slikar \\
\hline
\end{tabular}




\begin{tabular}{|c|c|c|c|}
\hline$\mu \varepsilon \lambda \varepsilon \gamma \gamma \rho \alpha \varphi \eta ́ \varsigma$ & 1 & fr. 627.1 & ispisan u pjesmama \\
\hline$\gamma \rho \alpha \pi \tau o ́ \varsigma$ & 1 & fr. $752 \mathrm{c} .2$ & naslikan \\
\hline & 1 & Bacch. 1067 & urezivati \\
\hline$\gamma \rho \alpha ́ \varphi \omega$ & 14 & $\begin{array}{c}\text { Hipp. } 859 \text { i } 1311, \text { IA } 35, \\
99 \text { i } 891, \text { Ion } 443, I T \\
\text { 585, Phoen. } 574, \\
\text { Supp. } 433 \text {, Tro. } \\
\text { 1189, fr. } 378.2, \text { fr. } \\
\text { 506.3 i 5, fr. } 578.7\end{array}$ & pisati \\
\hline$\delta 1 \alpha \gamma \rho \alpha ́ \varphi \omega$ & 1 & El. 1073 & prekrižiti \\
\hline$\dot{\varepsilon} \gamma \gamma \rho \alpha ́ \alpha \omega$ & 6 & $\begin{array}{l}\text { IA } 113 \text { i } 324, \text { IT } 760, \\
763 \text { i } 787, \text { Supp. } \\
1202\end{array}$ & pisati \\
\hline$\kappa \alpha \tau \alpha \gamma \rho \alpha ́ \alpha \omega$ & 1 & Alc. 968 & ispisati \\
\hline$\mu \varepsilon \tau \alpha \gamma \rho \alpha ́ \varphi \omega$ & 1 & IA 108 & iznova pisati \\
\hline vं & 1 & HF 1118 & skicirati \\
\hline \multicolumn{4}{|c|}{ Derivati od $\dot{\varepsilon} \pi 1 \sigma \tau \varepsilon \lambda \lambda$ - } \\
\hline \multirow[t]{2}{*}{$\dot{\varepsilon} \pi 1 \sigma \tau 0 \lambda \eta ́$} & 5 & $\begin{array}{l}\text { Andr. 964, Bacch. 442, } \\
\text { Hel. 1649, IT } 732 \text { i } \\
\quad 1446\end{array}$ & usmena zapovijed \\
\hline & 6 & $\begin{array}{c}\text { Hipp. 858, IA } 111 \text { i } 314, \\
\text { IT 589, } 767 \text { i } 786\end{array}$ & pismo \\
\hline \multirow{3}{*}{$\dot{\varepsilon} \pi t \sigma \tau \varepsilon \dot{\varepsilon} \lambda \lambda \omega$} & 3 & $\begin{array}{c}\text { Heracl. 938, Phoen. } \\
\text { 863, Tro. } 1149\end{array}$ & zapovijedati \\
\hline & 1 & El. 333 & slati usmenu poruku \\
\hline & 1 & $I T 770$ & slati pisanu poruku \\
\hline
\end{tabular}

U samo 45 konteksta (oko 33\%) termini su nepovezani s pisanjem $(20+16+9): 12$ je aluzija na sliku, ${ }^{48}$ po jednom je riječ o urezivanju, ciljnoj crti, precrtavanju i granici ${ }^{49}$ devet primjera (svi iz treće grupe) ko-

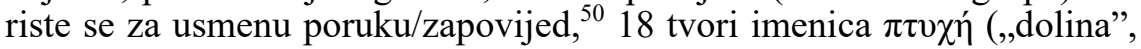
„nebo" i „nabor”) te dva imenica oaví (,paluba” i „,vrata”). Dvostruko je više termina koji su povezani s pisanjem $(90, \mathrm{tj} .67 \%) .{ }^{51}$ Iz prve grupe potječe njih 37 , iz druge 46 , a iz treće sedam. Metaforičko pisanje prona-

${ }^{48}$ Hec. 807, HF 1118, Hipp. 1005, Ion 271 i 1146, Phoen. 129 i 1135, Tro. 687, fr. 618.2 , fr. $752 \mathrm{c} .2$ te fr. $1059.5 \mathrm{~s}$ dva termina.

${ }^{49}$ Bacch. 1067, El. 956 i 10723 te fr. 169.

${ }^{50}$ Andr. 964, Bacch. 442, El. 333, Hel. 1649, Heracl. 938, IT 732 i 1446, Phoen. 863 te Tro. 1149.

${ }^{51}$ Alc. 967 i 968, Hec. 866, Hipp. 387, 451, 856, 858, 859, 865, 877, 879, 954, 1057, 1253 i 1311 (dva termina), IA 35 (dva termina), 37, 98 (dva termina), 99, 108, 109, 111, 112 (dva termina), 113, 116, 118, 155, 307, 314, 322 (dva termina), 324, 363, 798, 891 (dva termina) i 894, Ion 443, IT 584, 585, 589, 594, 603, 615, 636, 641, 667, 727 (dva termina), 733, 735, 745, 756, 760 (tri termina), 762, 763, 764, 767, 770, 786, 787 (dva termina), 791 i 793 (dva termina), Phoen. 574, Supp. 433 i 1202, Tro. 1189 i 1191, fr. 369.6, fr. 378.2, fr. $382.1,5$ i 11, fr. 506.2 (dva termina), 3 i 5, fr. 578.3 , 7 i 9, fr. 627.1 te fr. 923.2. 
đeno je tri puta; jednom u značenju „smatrati nekoga nekakvim”, a dvaput $u$ aluzijama na Zeusov zamišljeni zapis (= praćenje) ljudskih zločina. ${ }^{52}$ Nema metaforičkih poveznica pisanja i intelektualnih aktivnosti (pamćenja).

Potencijalno relevantni termini pronađeni su u svim dramama osim Med., ali analiza otkriva da su u samo devet sačuvanih drama doista povezani uz pisanje (Alc., Hec., Hipp., IA, Ion, IT, Phoen., Supp. i Tro.). U Euripidovu opusu ne samo da pronalazimo pisma, već upravo njihovi spomeni čine veliku većinu primjera povezanih s pisanjem, tj. njih 62 (što je 69\%): u Hip. devet, u IA 24, a u IT svih 29. Brojnost spomena pisama u ove tri tragedije objašnjava važnost koju imaju u fabulama: Fedra pismom uzrokuje Hipolitovu smrt, Agamemnon u $I A$ prvim pismom poziva Ifigeniju, a drugim, neisporučenim, pokušava joj spasiti život, dok u IT pismo omogućuje anagnorisis. ${ }^{53}$

\section{Skupni pregled termina s pripadajućim značenjima i njihova interpretacija}

Tablica 4. sadrži skupni pregled pronađenih termina, grupiranih prema približnim značenjima. Cilj je sinoptički prikazati njihovu distribuciju te ukazati na razlike u korištenju od autora do autora.

Tablica 4. Skupni pregled termina

\begin{tabular}{|c|c|c|c|c|c|}
\hline \multirow{2}{*}{ Termin } & \multirow{2}{*}{ Značenje } & \multicolumn{3}{|c|}{ Broj primjera } & \multirow{2}{*}{$\begin{array}{c}\text { Mjesto } \\
\text { pojavljivanja }\end{array}$} \\
\hline & & Eshil & Sofoklo & Euripid & \\
\hline \multicolumn{6}{|c|}{ Metonimijski termini } \\
\hline \multirow{2}{*}{$\beta \tilde{\beta} \beta \lambda$ o } & $\begin{array}{l}\text { papirus } \\
\text { (biljka) }\end{array}$ & 1 & - & - & Aesch.: Supp. 761 \\
\hline & $\begin{array}{l}\text { papirus } \\
\text { (materijal) }\end{array}$ & 1 & - & - & Aesch.: Supp. 947 \\
\hline \multirow[b]{2}{*}{$\delta \varepsilon ́ \lambda \tau \circ \varsigma$} & & & & & $\begin{array}{l}\text { Aesch.: } P V 789, \text { fr. } \\
\text { 281a.21 } \\
\text { Soph.: Trach. } 47, \\
157 \text { i } 683 \text {, fr. } 597\end{array}$ \\
\hline & $\begin{array}{l}\text { pločica } \\
\text { (za pisanje) }\end{array}$ & 2 & 4 & 32 & $\begin{array}{l}\text { Eur.: Hipp. } 856,865 \text {, } \\
\text { 877 i } 1057, \text { IA 35, } \\
\text { 98, 109, 112, 116, } \\
\text { 155, 307, 322, } \\
\text { 798, 891 i 894, IT } \\
\text { 584, 603, 615, }\end{array}$ \\
\hline
\end{tabular}

${ }^{52}$ Fr. 378.2 te fr. 506.1-3 i 5. Smatramo pogrešnim što Ceccarelli ubraja i El. 956 i fr. 169 (2013: 207, bilj. 78); pojmovi označavaju granicu i ciljnu crtu.

${ }_{53}$ Naratološka analiza uloge samih pisama u dramama prelazi okvire ovoga rada. $\mathrm{O}$ tome v. Rosenmeyer, 2001: 65 i Hajdarević, 2019: 7-11. 


\begin{tabular}{|c|c|c|c|c|c|}
\hline & & & & & $\begin{array}{l}636,641,667, \\
727,733,756, \\
760,787 \text { i } 791, \text { fr. } \\
369.6 \text {, fr. } 506.2 \text {, fr. } \\
578.9\end{array}$ \\
\hline$\delta \varepsilon \lambda \tau о \gamma \rho \alpha ́ \varphi о \varsigma$ & $\begin{array}{l}\text { koji piše na } \\
\text { pločicu }\end{array}$ & 1 & - & - & Aesch.: Eum. 275 \\
\hline$\delta \varepsilon \lambda \tau \tau^{\circ} \circ \mu \alpha$ & $\begin{array}{l}\text { pisati si na } \\
\text { pločice }\end{array}$ & 1 & - & - & Aesch.: Supp. 179 \\
\hline$\pi i ́ v \alpha \xi$ & $\begin{array}{l}\text { pločica za } \\
\text { pisanje }\end{array}$ & 3 & - & - & $\begin{array}{l}\text { Aesch.: Supp. } 463 \text { i } \\
\text { 946, fr. 281a.22 }\end{array}$ \\
\hline \multirow{4}{*}{$\pi \tau \nu \chi \eta ́ \eta \pi \tau \dot{\xi} \xi$} & stranica & 1 & - & 4 & $\begin{array}{l}\text { Aesch.: Supp. } 947 \\
\text { Eur.: IA } 98 \text { i } 112, I T \\
\quad 760, \text { fr. } 506.2\end{array}$ \\
\hline & dolina & - & 1 & 16 & $\begin{array}{l}\text { Soph.: OT } 1026 \\
\text { Eur.: Andr. } 1277, \\
\text { Bacch. 62, 797, } \\
945 \text { i } 1219, \text { Hel. } \\
44 \text { i } 605, H F 240, \\
\text { IT } 9 \text { i } 1082, \text { Or. } \\
\text { 1631 i 1636, } \\
\text { Phoen. 84, Supp. } \\
\text { 757, fr. 228a.20, fr. } \\
779.7\end{array}$ \\
\hline & nabor & - & 1 & 2 & $\begin{array}{l}\text { Soph.: fr. } 494 \\
\text { Eur.: Supp. } 212 \text { i } 979\end{array}$ \\
\hline & $\begin{array}{l}\text { pločica } \\
\text { (za pisanje) }\end{array}$ & - & 1 & - & Soph.: fr. 144.1 \\
\hline$\delta 1 \alpha \pi \tau v \chi \eta ́$ & stranica & - & - & 2 & Eur.: IT 727 i 793 \\
\hline \multirow{3}{*}{ 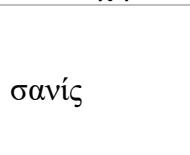 } & $\begin{array}{l}\text { pločica } \\
\text { (za pisanje) }\end{array}$ & - & - & 1 & Eur.: Alc. 967 \\
\hline & paluba & - & - & 1 & Eur.: Hel. 1556 \\
\hline & vrata & - & - & 1 & Eur.: Or. 1221 \\
\hline \multicolumn{6}{|c|}{ Derivati od $\gamma \rho \alpha \varphi-$} \\
\hline \multirow[t]{3}{*}{$\gamma \rho \alpha ́ \alpha \mu \alpha$} & slovo & 5 & 2 & 13 & $\begin{array}{l}\text { Aesch.: } P V 460, \\
\text { Sept. } 434,468, \\
646 \text { i } 660 \\
\text { Soph.: fr. } 144.1 \text {, fr. } \\
\text { 514 } \\
\text { Eur.: Hipp. } 387,954 \\
\text { i } 1253, I A 37,118 \\
\text { i } 322, \text { IT 594, } 745 \text {, } \\
\text { 764 i 793, fr. } \\
\text { 382.1, fr. 578.3, fr. } \\
\text { 923.2 }\end{array}$ \\
\hline & zapis & 1 & 1 & - & $\begin{array}{l}\text { Aesch.: fr. } 331 \\
\text { Soph.: fr. } 784\end{array}$ \\
\hline & slika & - & - & 2 & $\begin{array}{l}\text { Eur.: Ion 1146, fr. } \\
\quad 1059.5\end{array}$ \\
\hline
\end{tabular}




\begin{tabular}{|c|c|c|c|c|c|}
\hline \multirow[t]{2}{*}{$\dot{\varepsilon} \pi \dot{\gamma} \gamma \rho \alpha \mu \mu \alpha$} & natpis & - & - & 1 & Eur.: Tro. 1191 \\
\hline & crta & - & - & 2 & Eur.: El. 956, fr. 169 \\
\hline$\gamma \rho \alpha \mu \mu \eta ́$ & $\begin{array}{l}\text { crta } \\
\text { (u pisanju) }\end{array}$ & - & - & 2 & Eur.: fr. 382.5 i 11 \\
\hline \multirow[t]{2}{*}{$\gamma \rho \alpha \varphi \eta ́$} & slika & 3 & - & 7 & $\begin{array}{l}\text { Aesch.: Ag. } 242 \mathrm{i} \\
\text { 1329, Cho. } 232 \\
\text { Eur.: Hipp. } 1005 \text {, Ion } \\
271 \text {, Phoen. } 129 \mathrm{i} \\
\text { 1135, Tro. } 687 \text {, fr. } \\
\text { 618.2, fr. } 1059.5\end{array}$ \\
\hline & zapis & - & 1 & 7 & $\begin{array}{l}\text { Soph.: Trach. } 683 \\
\text { Eur.: Hec. } 866 \text {, Hipp. } \\
\text { 451, } 879 \text { i } 1311, I A \\
\text { 363, IT } 735 \text { i } 762\end{array}$ \\
\hline 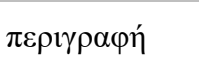 & $\begin{array}{l}\text { otisak } \\
\text { stopala }\end{array}$ & 1 & - & - & Aesch.: Cho. 207 \\
\hline 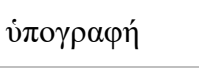 & $\begin{array}{l}\text { otisak } \\
\text { stopala }\end{array}$ & 1 & - & - & Aesch.: Cho. 209 \\
\hline$\gamma \rho \alpha \mu \mu \alpha \tau \varepsilon v ́ \varsigma$ & tajnik/pisar & 1 & - & - & Aesch.: fr. 358.2 \\
\hline 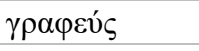 & slikar & - & - & 1 & Eur.: Hec. 807 \\
\hline$\mu \varepsilon \lambda \varepsilon \gamma \gamma \rho \alpha \varphi \eta ́ \varsigma \varsigma$ & $\begin{array}{l}\text { ispisan } \\
\text { pjesmama }\end{array}$ & - & - & 1 & Eur.: fr. 627.1 \\
\hline 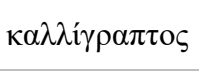 & $\begin{array}{l}\text { lijepo } \\
\text { obojan }\end{array}$ & 1 & - & - & Aesch.: fr. 78a.12 \\
\hline$\gamma \rho \alpha \pi \tau o ́ s$ & naslikan & - & - & 1 & Eur.: fr. 752 c. 2 \\
\hline$\alpha ̈ \gamma \rho \alpha \pi \tau \sigma \varsigma$ & nepisan & - & 1 & - & Soph.: Ant. 454 \\
\hline \multirow{3}{*}{$\gamma \rho \alpha ́ \varphi \omega$} & slikati & 2 & - & - & $\begin{array}{l}\text { Aesch.: Ag. 801, } \\
\text { Eum. } 50\end{array}$ \\
\hline & pisati & 4 & 3 & 14 & $\begin{array}{l}\text { Aesch.: Cho. } 450 \mathrm{i} \\
\text { 451, Supp. } 709 \mathrm{i} \\
\text { 991 } \\
\text { Soph.: OT 411, Phil. } \\
\text { 1325, fr. } 811 \\
\text { Eur.: Hipp. } 859 \mathrm{i} \\
\text { 1311, IA 35, } 99 \mathrm{i} \\
\text { 891, Ion 443, IT } \\
\text { 585, Phoen. } 574 \text {, } \\
\text { Supp. } 433, \text { Tro. } \\
\text { 1189, fr. 378.2, fr. } \\
\text { 506.3 i 5, fr. } 578.7\end{array}$ \\
\hline & urezivati & - & - & 1 & Eur.: Bacch. 1067 \\
\hline$\delta 1 \alpha \gamma \rho \alpha ́ \varphi \omega$ & prekrižiti & - & - & 1 & Eur.: El. 1073 \\
\hline$\dot{\varepsilon} \gamma \gamma \rho \alpha ́ \varphi \omega$ & pisati & 4 & 1 & 6 & $\begin{array}{l}\text { Aesch.: Cho. 699, } \\
\text { PV 789, Supp. } 946 \\
\text { i } 991 \\
\text { Soph.: Trach. } 157 \\
\text { Eur.: IA } 113 \text { i } 324, I T \\
\quad 760,763 \text { i } 787, \\
\text { Supp. } 1202\end{array}$ \\
\hline 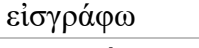 & pisati & - & 1 & - & Soph.: Trach. 1167 \\
\hline$\kappa \alpha \tau \alpha \gamma \rho \alpha ́ \varphi \omega$ & ispisati & - & - & 1 & Eur.: Alc. 968 \\
\hline
\end{tabular}




\begin{tabular}{|c|c|c|c|c|c|}
\hline$\mu \varepsilon \tau \alpha \gamma \rho \alpha ́ \varphi \omega$ & iznova pisati & - & - & 1 & Eur.: $I A 108$ \\
\hline ن் $\pi о \gamma \rho \alpha ́ \varphi \omega$ & skicirati & - & - & 1 & Eur.: $H F 1118$ \\
\hline \multicolumn{6}{|c|}{ Derivati od $\dot{\varepsilon} \pi \imath \tau \varepsilon \lambda \lambda$ - } \\
\hline \multirow[t]{2}{*}{$\dot{\varepsilon} \pi 1 \sigma \tau о \lambda \eta ́$} & $\begin{array}{l}\text { usmena } \\
\text { zapovijed }\end{array}$ & 4 & 4 & 5 & $\begin{array}{l}\text { Aesch.: Pers. 783, } \\
\text { PV 3, Supp. 1012, } \\
\text { fr. } 293 \\
\text { Soph.: Aj. 781, OC } \\
\text { 1601, Trach. 493, } \\
\text { fr. } 128 \\
\text { Eur.: Andr. } 964, \\
\text { Bacch. } 442, \text { Hel. } \\
\text { 1649, IT } 732 \mathrm{i} \\
1446\end{array}$ \\
\hline & pismo & - & - & 6 & $\begin{array}{l}\text { Eur.: Hipp. 858, IA } \\
\quad 111 \text { i } 314, \text { IT 589, } \\
767 \text { i } 786\end{array}$ \\
\hline \multirow[t]{3}{*}{$\dot{\varepsilon} \pi \imath \tau \tau \dot{\varepsilon} \lambda \lambda \omega$} & zapovijedati & 5 & 1 & 3 & $\begin{array}{l}\text { Aesch.: Ag. 908, } \\
\text { Cho. 779, Eum. } \\
205 \text { i 743, Sept. } \\
1012 \\
\text { Soph.: OT } 106 \\
\text { Eur.: Heracl. 938, } \\
\text { Phoen. 863, Tro. } \\
1149\end{array}$ \\
\hline & $\begin{array}{l}\text { slati usmenu } \\
\text { poruku }\end{array}$ & - & - & 1 & Eur.: El. 333 \\
\hline & $\begin{array}{l}\text { slati pisanu } \\
\text { poruku }\end{array}$ & - & - & 1 & Eur.: IT 770 \\
\hline
\end{tabular}

Broj primjera u Euripidovim dramama trostruko je veći nego u Eshilovim, a šesterostruko veći nego u Sofoklovim dramama.

Metonimijski termini najzastupljeniji su i najraznolikiji u Eshilovim dramama, a pronalazimo i četiri koja drugi autori ne koriste: $\beta v ́ \beta \lambda o \varsigma$,

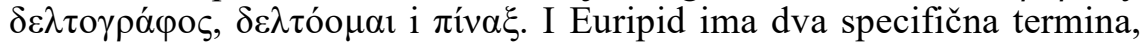

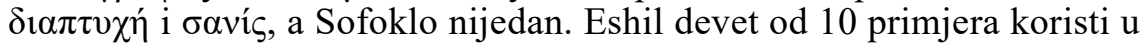
poveznici s pisanjem (dakle, 90\%), Sofoklo pet od sedam (71\%), a Euripid 37 od 57 (65\%). Od riječi koje se pojavljuju kod sva tri autora,

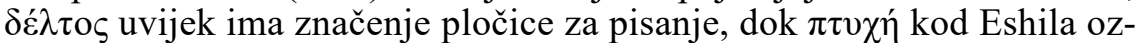
načava stranicu, kod Sofokla pločicu za pisanje, a Euripid je četiri puta koristi za „stranicu”, a 18 puta u drugim, s pisanjem nepovezanim značenjima. Sva četiri specifična Eshilova termina imaju veze s pisanjem, a isto vrijedi i za Euripidove.

Situacija među derivatima korijena $\gamma \rho \alpha \varphi$ - raznolikija je. Euripid ima

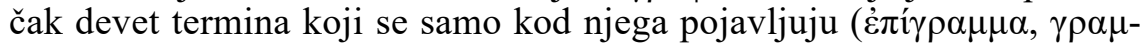

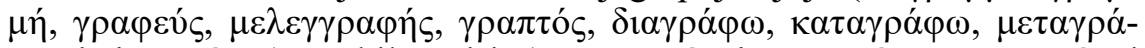

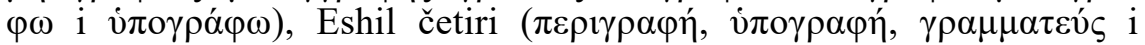

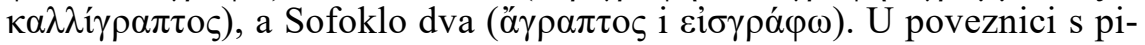


sanjem koristi se 15 od 23 Eshilova primjera (što je 65\%), svih 10 Sofoklovih te 47 od 62 Euripidova (76\%). Termini ove kategorije najčešće se pojavljuju te kod sve trojice autora tvore najveći broj aluzija na pisanje. Eshil njima šest puta aludira na slikanje, Euripid dvanaest puta, a Sofoklo, zanimljivo, nijednom. Euripid koristi najviše složenica glagola $\gamma \rho \alpha ́ \varphi \omega$ (pet od šest pronađenih).

Derivate korijena $\dot{\varepsilon} \pi \iota \tau \varepsilon \lambda \lambda$ - pronalazimo devet puta u Eshilovim i pet u Sofoklovim dramama, uvijek u značenju usmenih zapovijedi. Euripid ih pak sedam (od 16) puta koristi u poveznici s pisanim porukama. Nadalje, dok se termini relevantni za pisanje iz ostalih kategorija pojavljuju kroz širi spektar njegovih tragedija, ova dva derivata ograničena su na Hip., IA i IT, tragedije usko povezane uz pisma.

Metaforičko „zapisivanje” kao ekvivalent pamćenja pojavljuje se u Eshilovim i Sofoklovim, ali ne i Euripidovim dramama. ${ }^{54}$

\section{Zaključak}

Fragmentarna očuvanost grčke tragedije kao književne podvrste nalaže da se svi dobiveni rezultati interpretiraju vrlo oprezno. Izbor drama koje su do nas došle nipošto ne smijemo smatrati reprezentativnim, stoga su i uočene tendencije možda drugačije no što bi bile tendencije cjelokupne vrste $\mathrm{i} / \mathrm{ili}$ čitavih opusa trojice autora. Pri interpretaciji treba voditi računa i o tome da se Euripidovih drama sačuvalo dvostruko više no Eshilovih i Sofoklovih. Ipak, i na ovako malom uzorku drama iskristalizirale su se važne sličnosti, ali i poneke razlike među autorima koje smatramo uočljivima i značajnima.

Daleko najveći broj termina potencijalno povezanih s pisanjem pronađen je u Euripidovim dramama i fragmentima (čak 135), slijede Eshilove (42) pa Sofoklove (22). Isti je redoslijed i s brojem korištenih riječi $(19,16$ i 10). Dokazano je da sva tri autora aludiraju na pisanje (bilo pravo ili metaforičko), ${ }^{55}$ a osvrću se i na izumitelje pisma/pisanja: Eshil spominje Prometeja ( $P V$ 460), Sofoklo Kadma (fr. 514), a Euripid Palameda (fr. 578.3). U Eshilovim dramama pravo i metaforičko pisanje pronalazimo podjednako često, Sofoklo četiri puta češće aludira na pravo, a Euripid čak 30 puta češće.

Kod sve trojice autora zastupljenošću prednjače derivati korijena $\gamma \rho \alpha \varphi$ - (čine oko polovinu svih primjera), slijede metonimijski termini, a najmanje česti su derivati od $\dot{\varepsilon} \pi 1 \sigma \tau \varepsilon \lambda \lambda$-. Najmanji postotak termina po-

${ }^{54}$ Smrtnici trebaju „zapisivati u um”, tj. pamtiti (kor u Cho., Filoktet u Phil., Danajeve kćeri u Supp. i Ija u $P V$ ), a bogovi, naravno, ne; zamišljeni su kao sveznajući vlasnici metaforičkih ,zapisa”.

${ }^{55}$ Bez pisanja tragedija ne bi ni postojala (glumci su pamtili napisani tekst) i ne treba nas iznenaditi što tragičari u drame uključuju reference na pisanje, možda kao svojevrsni dokaz svjesnosti svoga ,duga” toj vještini. Slično i Ceccarelli, 2013: 185 (bilj. 8). 
vezanih s pisanjem je u Eshilovim dramama (oko 52\%), dok je kod druge dvojice znatno viši (68 odnosno 67\%). Osim toga, Eshil i Sofoklo derivatima od $\dot{\varepsilon} \pi \sigma \tau \varepsilon \lambda \lambda$ - baš nikada ne aludiraju ni na što zapisano. U Euripidovim je dramama drugačije: devet njegovih primjera odnosi se na usmene poruke, ali drugih sedam na pisane (tj. pisma).

Pojedine termine autori koriste u jednakom značenju (npr. $\delta \varepsilon ́ \lambda \tau o \varsigma \mathrm{i}$ $\dot{\varepsilon} \gamma \gamma \rho \alpha ́(\varphi)$, dok pri upotrebi drugih nailazimo na varijacije. Imenica $\pi \tau v-$ $\chi \eta ́$ ima čak četiri značenja (,,stranica”, ,dolina”, ,nabor” i „pločica za pisanje"), no barem po jednom kod sve trojice povezana je s kontekstom pisanja. I značenja imenice $\gamma \rho \alpha ́ \mu \mu \alpha$ variraju: uobičajeno označava slova ili zapis, ali u Euripidovom slučaju dvaput znači „slika”. Nadalje, $\gamma \rho \alpha \varphi \eta ́$ Eshil koristi isključivo u značenju slike, Sofoklo samo kao „zapis", dok Euripid podjednako koristi oba značenja. Glagol $\gamma \rho \alpha ́$ ́ $\varphi \omega$ uobičajeno im znači „pisati”, no Eshilu dvaput i „slikati”, a Euripidu jednom

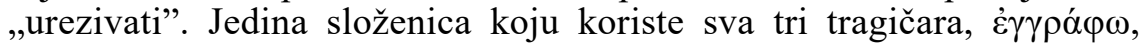
beziznimno znači ,pisati”, a s pisanjem su povezane i ostale složenice

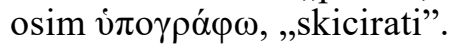

Eshil jedini koristi termin $\beta v ́ \beta \lambda o \varsigma$ (jednom povezano, jednom nepovezano s pisanjem). Ostali za njega specifični termini su: $\delta \varepsilon \lambda \tau o \gamma \rho \alpha ́(\varphi o \varsigma$,

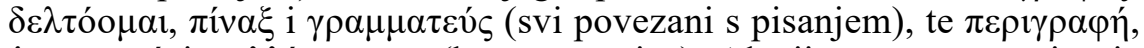

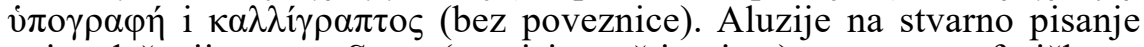
najnaglašenije su u Sept. (natpisi na štitovima), a na metaforičko u Supp. Potonje često sadrži poveznicu pisanja i pamćenja (usp. ,pisati na pločice uma"); čak je šest takvih primjera.

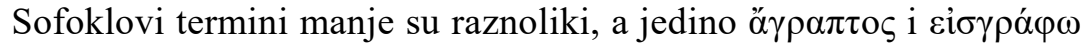
ne pronalazimo kod drugih autora (oba s poveznicom s pisanjem). Sofoklo koristi čak triput manje metaforičkih aluzija na pisanje od Eshila. U

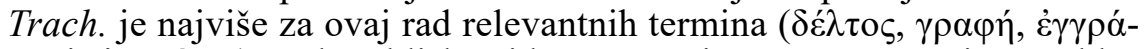
$\varphi \omega$ i $\varepsilon i \sigma \gamma \rho \alpha ́(\varphi \omega)$, a zbog bliskosti konceptu pisma važna nam je Heraklova oporuka: obraća se supruzi pisanim dokumentom privatnoga sadržaja, između vremena njihova pisanja i čitanja postoji temporalni odmak (sve tipično za epistolarnu komunikaciju), a dokument je namijenjen Dejaniri (ekvivalent adresiranju).

U Euripidovim tragedijama i fragmentima najveća je raznolikost

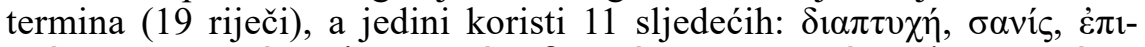

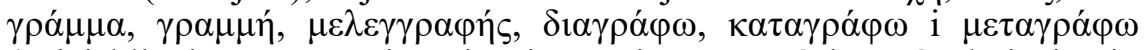

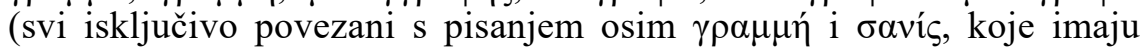

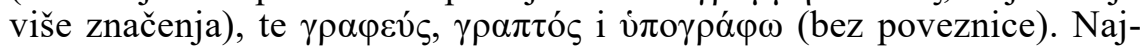
zanimljiviji primjer je fragment u kojemu nepismeni pastir slovka Tezejevo ime, opisujući izgled slova. Samo su dva metaforička spomena pisanja, ali, za razliku od Eshila i Sofokla, autor ih ne povezuje uz pamćenje.

Najveća i najvažnija razlika među autorima uočena je u korištenju derivata korijena غ̇ $\pi 1 \sigma \tau \varepsilon \lambda \lambda$-: Eshil i Sofoklo isključivo ih koriste u značenju usmenih zapovijedi, a Euripid i za pisane poruke (pisma). 
Iako je pronađeno ukupno znatno manje potencijalno relevantnih termina u Sofoklovim nego u Eshilovim dramama, uočavamo da je u Sofoklovim viši postotak onih čija je upotreba povezana s pisanjem (68\% naspram 52\% Eshilovih), a postotak je visok i u Euripidovim dramama. ${ }^{56}$ Euripid je pridao veliku važnost pisanju u radnji svojih tragedija, a u njih uključuje i pisma. Na pisma se aludira terminima iz sve tri grupe; čak 62 spomena otpadaju na aluzije na njih, što je $69 \%$ od svih spomena pisanih dokumenata, odnosno, čak $46 \%$ od ukupnog broja termina! I brojnost termina koji se odnose na pisanje i kompleksna uloga koju je Euripid dodijelio pismima u svojim zapletima / raspletima zacijelo zrcale postupno širenje pismenosti i popularnosti komunikacije pismima u grčkome društvu kasne Klasike; u njegovim dramama pojavljuju se od 428. nadalje (Hip.). Uočena je i druga važna odrednica: dok u dramama drugi pisani dokumenti mogu imati i pozitivne i negativne konotacije, pomagati ili odmagati protagonistima (kao i usmene poruke), pisma su u gotovo svim slučajevima obojena negativno, često su lažna i/ili opasna.

I postupno smanjenje metaforičke upotrebe termina (Eshil ima 11, a Sofoklo i Euripid samo po dva takva primjera) i činjenicu da su u Euripidovim dramama iščezla metaforička "pisanja na pločice uma" dijelom objašnjava spomenuto „udomaćivanje” pisanja u grčkoj svakodnevici. ${ }^{58}$ Ipak, potrebno je napomenuti da unutar Eshilova i Sofoklova opusa nije uočeno njihovo nestajanje objašnjivo kronološkim odrednicama; primjere pronalazimo i u njihovim kasnijim dramama (usp. „pisanje na pločice" boga Hada u Eum. iz 458, odnosno poveznicu pisanja i pamćenja u Sofoklovu Filoktetu iz 409). Očito su na izbjegavanje ovakve metaforičke upotrebe dijelom utjecale i Euripidove osobne preferencije (koje, dakako, ne možemo objasniti).

${ }^{56}$ Vjerojatno su i same karakteristike odabranih mitoloških priča pritom imale utjecaja; u neke je lakše implementirati poveznicu s pisanjem, u druge teže.

${ }^{57}$ Iako potencijalno spasonosno (drugo) pismo iz IA i Ifigenijino pismo iz IT djeluju kao iznimke, u $I A$ otkrivanje sadržaja pisma vojsci moglo je dovesti Agamemnona u smrtnu opasnost, a Ifigenija je svoje pismo izdiktirala osobi koja je naknadno pogubljena.

${ }^{58}$ Smatramo logičnim da se pisanje, nakon što je postalo uobičajena i općeraširena aktivnost, rjeđe koristi na metaforički način i/ili povezuje uz sferu apstraktnosti i božanstava. 


\section{BIBLIOGRAPHY}

Basta Donzelli, Giuseppina (ur). Electra. Berlin, De Gruyter, 2013.

Biehl, Werner (ur.). Troades. Berlin, De Gruyter, 2013.

Ceccarelli, Paola. Ancient Greek Letter Writing. A Cultural History (600-150 BC). Oxford, Oxford University Press, 2013.

Daitz, Stephen (ur.). Hecuba. Berlin, De Gruyter, 2013.

Dawe, Roger (ur.). Oedipus Rex. Cambridge: Cambridge University Press, 1982.

Dawe, Roger (ur.). Aiax. Berlin, De Gruyter, 2013a.

Dawe, Roger (ur). Antigone. Berlin, De Gruyter, 2013b.

Dawe, Roger (ur.). Oedipus Coloneus. Berlin, De Gruyter, 2013c.

Dawe, Roger (ur.). Philoctetes. Berlin, De Gruyter, 2013d.

Dawe, Roger (ur.). Trachiniae. Berlin, De Gruyter, 2013e.

Diggle, James (ur.). Euripidis Fabulae: Vol. II. Oxford, Clarendon Press, 1981.

Diggle, James (ur.). Euripidis Fabulae: Vol. I. Oxford, Clarendon Press, 1984.

Diggle, James (ur.). Euripidis Fabulae: Vol. III. Oxford, Clarendon Press, 1994.

Garvie, A. F. (ur.). Choephori. Oxford, Oxford University Press, 1986.

Garzya, Antonio (ur.). Alcestis. Berlin, De Gruyter, 2011a.

Garzya, Antonio (ur.). Heraclidae. Berlin, De Gruyter, 2011 b.

Gunther, Martin (ur.). Ion. Berlin, De Gruyter, 2018.

Günther, Hans Christian (ur.). Iphigenia Aulidensis. Berlin, De Gruyter, 2010.

Hajdarević, Sabira. „Pisanje (pisama) u Euripidovim tragedijama”. Književna smotra 51, 193, 3 (2019), 3-13.

Hornblower, Simon i Spawforth, Antony (ur.). The Oxford Classical Dictionary. Oxford, Oxford University Press, $2012^{4}$.

Jebb, R. C. (ur.). The Plays and Fragments V. Cambridge, Cambridge University Press, 1892.

Jenkins, Thomas. Intercepted Letters. Epistolarity and Narrative in Greek and Roman Literature. Lanham, Lexington Books, 2006.

Kannicht, Richard (ur.). Tragicorum Graecorum Fragmenta. Vol. 5, Göttingen, Vandenhoeck \& Ruprecht, 2004.

Kopff, Christian (ur.). Bacchae. Berlin, De Gruyter, 2018.

Liddell, Henry i Scott, Robert. A Greek-English Lexicon. Oxford, Clarendon Press, 1940.

Marconi, Clemente. „Early Greek Architectural Decoration in Function”. U: Mediterranean Studies in Honor of R. R. Holloway, ur. Counts, D. B. i Tuck, A. S., Oxford, Oxbow Books, 2009, 4-17.

Mastronarde, Donald (ur.). Phoenissae. Berlin, De Gruyter, 2013.

Radt, Stefan (ur.). Tragicorum Graecorum Fragmenta. Vol. 3, Göttingen, Vandenhoeck \& Ruprecht, 1985.

Radt, Stefan (ur.). Tragicorum Graecorum Fragmenta. Vol. 4, Göttingen, Vandenhoeck \& Ruprecht, 1999.

Rosenmeyer, Patricia. Ancient Epistolary Fictions. The Letter in Greek Literature. Cambridge, Cambridge University Press, 2001.

Stockert, Walter (ur.). Hippolytus. Berlin, De Gruyter, 2013.

West, Martin (ur.). Aeschyli Agamemnon. Berlin, De Gruyter, 2012a.

West, Martin (ur.). Aeschyli Choephoroe. Berlin, De Gruyter, 2012b.

West, Martin (ur.). Aeschyli Eumenides. Berlin, De Gruyter, 2012c.

West, Martin (ur.). Aeschyli Persae. Berlin, De Gruyter, 2013a.

West, Martin (ur.). Aeschyli Prometheus. Berlin, De Gruyter, $2013 \mathrm{~b}$.

West, Martin (ur.). Aeschyli Septem contra Thebas. Berlin, De Gruyter, 2013c.

West, Martin (ur.). Aeschyli Supplices. Berlin, De Gruyter, 2013d. 
Sabira HAJDAREVIĆ

Ivan BRAICA

\section{REFERENCES TO WRITING IN GREEK TRAGEDIES - summary -}

All Greek tragedies that came down to us except Aeschylus' Persians are based on various mythological stories situated in the Mycenaean period (it is dated usually between 1600 and $1200 \mathrm{BC}$ ), which was primarily characterised by oral communication. Therefore, references to writing in the fabulas of Greek tragedies are in fact a huge anachronism. Nevertheless, some of the terms that denote written documents, e.g. inscriptions in stone or on warriors' shields, lists, laws and letters, are sporadically found in the surviving dramas and dramatic fragments.

This paper deals with the terms referring to (or alluding to) the act of writing or the resulting scripts in Aeschylus', Sophocles' and Euripides' extant dramas and fragments. Naturally, the first point of reference were the derivatives of the root $\gamma \rho \alpha \varphi$ - (nouns, adjectives and verbs): $\gamma \rho \alpha \dot{\alpha} \mu \alpha \alpha, \dot{\varepsilon} \pi \dot{\prime} \gamma \rho \alpha \mu \mu \alpha$,

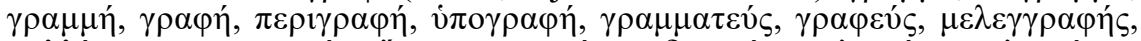

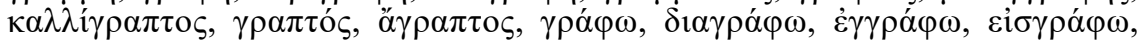

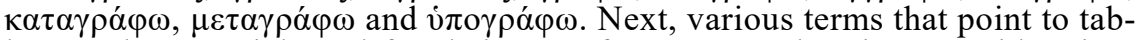
lets or the material used for their manufacture are taken into consideration; these terms can denote the material, the tablet, but also the very document written upon it (therefore these terms are referred to as metonymical terms in

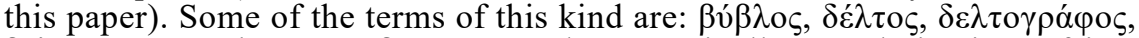

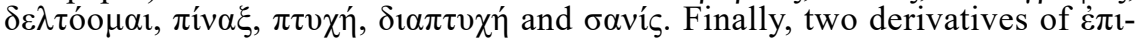
$\sigma \tau \varepsilon \lambda \lambda$ - are included: the noun $\dot{\varepsilon} \pi 1 \sigma \tau \mathrm{o} \lambda \eta \dot{~ i n ~ G r e e k ~ p o i n t s ~ t o ~ a n y ~ k i n d ~ o f ~ m e s s a-~}$ ge, including a written one (i.e. a letter; this meaning is more frequent from Hellenistic period onwards), and the verb $\dot{\varepsilon} \pi \_\tau \dot{\varepsilon} \lambda \lambda \omega$ signifies the sending of oral, as well as written messages (i.e. letters) with the help of a messenger.

As a starting point, all terms potentially connected to writing (as listed above) are detected and extracted from surviving tragedies and available tragic fragments. The search is conducted by the use of two important tools: Diogenes (the desktop/laptop application for searching and browsing the legacy databases of texts in Latin and ancient Greek) and the online data base $T L G$ - Thesaurus Linguae Graecae. As the next step, the context of the verses in which the terms appear is carefully analysed, and the terms are catalogued according to their approximate meaning (e.g. a tablet, a painting, a piece of writing, written laws, a letter etc.). The analyses in question are conducted separately on the opuses of the three authors; each individual research is followed by a concise table, consisting of the total of the terms used by the author in question, their location in dramas (with the abbreviated title and the verse number noted) and their approximate meaning.

In the end, the individual results obtained are meticulously compared, the frequency of all terms in dramas of the three tragedians is determined and an analysis of whether or not the authors use the most important terms equally is conducted.

The final aim of this paper is to point to similarities and also potential differences regarding the very choice of the terms referring to writing and/or their usage (i.e. the meaning they achieve) in tragedies of the three Greek master playwrights of the Classical era. 